\title{
THE IMPACT OF FLOODPLAIN VEGETATION ON THE EROSION-SEDIMENTATION PROCESSES IN FLUVISOLS DURING FLOOD EVENTS
}

\author{
BELČÁKOVÁ, I. ${ }^{1}$ - VOJTKOVÁ, J. ${ }^{2 *}$ - PAUKOVÁ, Ž. ${ }^{3}$ - OFFERTÁLEROVÁ, M. ${ }^{1}$ \\ ${ }^{1}$ Faculty of Ecology and Environmental Sciences, Technical University in Zvolen \\ T. G. Masaryka 24, 96053 Zvolen, Slovakia \\ (phone: +421-455-206-492; fax: +421-455-206-279) \\ ${ }^{2}$ Faculty of Civil Engineering, Slovak University of Technology in Bratislava \\ Radlinského 11, 81005 Bratislava, Slovakia \\ (phone: 421-2-5927-4471; fax: +421-2-5296-7027)
}

${ }^{3}$ Faculty of European Studies and Regional Development, Slovak Agricultural University

tr. A. Hlinku 2, 94976 Nitra, Slovakia

(phone: +421-376-415-7292; fax: +421-376-531-522)

*Corresponding author

e-mail: belcakova@tuzvo.sk; phone: 421-908-899-229

(Received $4^{\text {th }}$ Nov 2018; accepted 21 $1^{\text {st }}$ Mar 2019)

\begin{abstract}
Limiting factors for riparian ecosystem were previously considered to be riparian habitat structure, water flow variability, sedimentation and erosion. Recent scientific research have started to focus their attention to the feedback between form and function in fluvial ecosystems considering that not only geomorphology controls riparian vegetation dynamics, but also riparian vegetation controls geomorphology. Erosion-sedimentation processes significantly change the channel of the river and its surroundings and the sediment movement indicator is the critical value of the shear stress. This contribution deals with the impact of vegetation on the erosion-sedimentation processes in fluvisols during flood events. Selected vegetation characteristics and their effects on the humus horizons in fluvisols were assessed at the selected area of the River Schwechat followed by modelling of the shear stress during flood events.
\end{abstract}

Keywords: riparian ecosystem, floodplain water, biogeomorphic processes, landform dynamics, hydraulic modelling, Schwechat River

\section{Introduction}

Riparian ecosystems are transitional semiterrestrial areas regularly influenced by fresh water, usually extending from the edges of water bodies to the edges of upland communities. Because of their spatial position, they integrate interactions between the aquatic and terrestrial components of the landscape. They are dynamic environments characterized by strong energy regimes, substantial habitat heterogenity, a diversity of ecological processes, and multidimensional gradients (Daigneault et al., 2017). Habitat for riverine and riparian organisms is a constantly changing mosaic biophysically dynamic in space and time. In his context, the biota is uniquely adapted to the dynamics of the system (Dufour et al., 2015). Riparian ecosystems are often locations of concentrated biodiversity at regional to continental scales.

Interactions between riparian vegetation and fluvial hydraulic processes are regulated by the flow regime which is one of the primary drivers shaping morphological patterns and ecological integrity (Wohl et al., 2015; Claude et al., 2018). One of the outcomes of 
these complex interactions are discrete vegetation units that represent snapshots in time characterized by stands of different age and structural features (Egger et al., 2013a, b). Riparian species have developed adaptations and synchronized life history traits with the variable conditions of the river dynamics (Kui et al., 2014; Kui and Stella, 2016). When fluvial characteristics are modified, riparian plant communities and vegetation structure change favouring less bio-diverse environments, worse water quality and more exposed river beds (Stallings et al., 2015), definitely leading to a poor or bad ecological status. In many cases, to achieve a good ecological status of water body can be crucial for the riparian vegetation protection in order to support its hydrological and ecological functions (Garcia-Arias and Francés, 2015; Macura et al., 2012).

As pointed out by Sponseller et al. (2013), running water ecosystems illustrate several principles governing the interaction of landscape form and ecological function. Whereas the control of sediment dynamics by hygromorphic plants has been identified as an important component of intertidal ecosystem function (Passarelli et al., 2014; O'Brian et al., 2018; Kazakova, 2018; Varigin, 2018), the effect of riparian vegetation on sediment erosion and deposition within fluvial systems has been studied mainly from the geomorphic perspective of landform dynamics (Bywater-Reyes et al., 2015).

Fluvial biogeomorphic studies suggested that the geomorphic effects (flow resistance, sediment stabilization and accretion) and biomechanical and life history responses (mechanical resistance, reproduction, dispersion, and growth) of riparian vegetation within and between floods may represent key controls on both the riparian ecosystem and landscape dynamics. Thus, the effects of riparian vegetation on sediment erosion/deposition dynamics may form a biogeomorphic function regulating conjointly succession, biodiversity and landform dynamics within fluvial corridors (van Dijk et al., 2014; Corenblit et al., 2014a). Biogeomorphic approaches are recently investigating back mechanisms between biota, topography and landscape dynamics (Correnblit et al., 2014b; van Oorschot et al., 2017; Dyderski et al., 2015; Gonzales et al., 2014, 2015; Arnold and Toran, 2018).

Riparian ecosystems often represent locations of concentrated biodiversity, and flooding is one of the most important factors accounting for the remarkably high biodiversity associated with the riparian zones (Tagwirey and Sullivan, 2015). Floods recharge the floodplain water table and provide seedlings with access to moist soils, create new sites for plant recruitment, flush organic material such as woody debris, deposit nutrients onto the floodplain and disperse seeds of riparian plants (Warner et al., 2014). The physiological effect of a flood event depends on an individual plant tolerance (Egger et al., 2013a). The most important flood factors affecting plants are flood level and relative water depth, flood duration, flood timing and time since the last flood event.

Because of the sensitivity to the hydrological regime, riparian vegetation composition, structure and vigour respond rapidly to flow regime changes (Boudell et al., 2015; Wohl et al., 2015). Hydrological changes sometimes result in the encroachment of river margins by native riparian species (e.g. Merrit, 2013; Sankey et al., 2015). In other cases, native species may loose their vigour (e.g. Havel et al., 2015; Li, 2013; Gonzalez et al., 2014) and may be replaced by other native or alien species that have different hydrological requirements and tolerances (e.g. Garssen et al., 2014; Capon et al., 2013; Catford et al., 2014).

Morphodynamic processes associated with floods such as sediment deposition/aggradation and fluvial erosion result in the physical disturbances. These 
disturbances determine species diversity, population recruitment and survival, and the age structure of stands (Solari et al., 2015; Kath et al., 2014; Kondolf and Piégay, 2016). The extent and intensity of flood disturbance can be measured by its destructive impact on the vegetation (Mobaied et al., 2016).

Erosion of sediments during flood events can be estimated by a critical shear stress. When the flow conditions exceed a critical value, sediment particles on the stream bed start to move. The ability of a particle to move is related to hydraulic shear stress, frictional forces, water depth and the specific weight of the particle (Lamb et al., 2017). Riparian vegetation dynamics depends on hydrogeomorphologic parameters (Operman et al., 2017), and, in return, on living and dead riparian plants modulate sediment, diaspore, nutrient and water flows within fluvial corridors (Funk et al., 2018; Habersack et al., 2016). Fluvial corridors are constituted of river channels, their margins and the zone of expansion of frequent floods, occupied by riparian vegetation (Kim and Kupfer, 2016). The ability of some riparian plants to grow on deposited sediment implies that sediment deposition favours plant biomass production. In return, biomass production then increases surface roughness and sediment deposition (Thomas et al., 2015; Corenblit et al., 2014a). Many studies (Camporeale et al., 2013; Clarke et al., 2014; Eichel et al., 2013) suggest that vegetation plays key roles in determining fluvial ecosystem structure, function and channel geometry. During floods many riparian species reproduce both vegetatively and sexually and a lot of sediments are transported with the flow. Vegetation reduces velocity and shear stress on the interface between vegetation patch and flow (Rössler et al., 2018; Hession et al., 2013; Gilyear et al., 2017) that causes increasing sediment deposition within and behind vegetation patches (Surian et al., 2015). The decrease of the shear stress depends on the vegetation density (Rivaes et al., 2014).

The main goal of our research was to find out how important role can riparian vegetation have when it comes to protection of the floodplain soils in the selected area. The research investigates the impact of riparian vegetation on the sediment erosion in floodplain area of River Schwechat in Austria. Another part of our research aimed at the determination of shear stress values exerted in the soil surface during flood events using hydraulic modelling and, also, to assess its impact on erosion-accumulation processes. This impact was surveyed during one big flood, which occurred in spring of 2014 being the biggest flood event in the area of River Schwechat since year 2007.

\section{Materials and methods}

The focus of the work consisted of the application of theoretical and methodological approaches in the field of landscape ecology, biogeomorphology, hydrology, geobotany, geographic information systems (GIS) and remote sensing. Furthermore, applied methodology of our research was adopted and modified from the paper of Corenblit et al. (2009, 20014a, b, 2015).

Based on field measurements, a first task was to distinguish different vegetation types and groups followed by series of phytocoenological relevés that were conducted not only in the measured area but in the whole surrounding. That gave us quite clear idea about vegetation types and their characteristics present in the area of interest. Subsequently, humus horizon thickness was calculated and particle size survey was performed. 
Selected vegetation characteristics and their effects on the humus horizons in fluvisols were then statistically assessed followed by modelling of the shear stress during flood events.

\section{The study area}

The study site at River Schwechat is located in the Baden district at the south-eastern part of lower Austria about $20 \mathrm{~km}$ south of Vienna. Our reference site is located near the

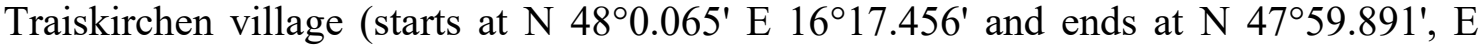
$16^{\circ} 16.921^{\prime}$, see Fig. 1). The area is part of the floodplain forest around the river Schwechat and is protected as a natural monument. Schwechat flows through most of the south-eastern part of lower Austria. The highest point is at Schwechat Schöpfl at $893 \mathrm{~m}$ above sea level. With a slight bow, it flows from its origin in the north-east ending at Mannswörth (Schwechat) at $162 \mathrm{~m}$ above sea level with its water mouth into the Danube.

A large part of the catchment area is the southern part of the Wienerwald. Within the streams of Agsbach, Lammeraubach and Sattelbach the runoff flows into Schwechat near Baden. The Sattelbach, which joins in the same named village, is the largest tributary stream.

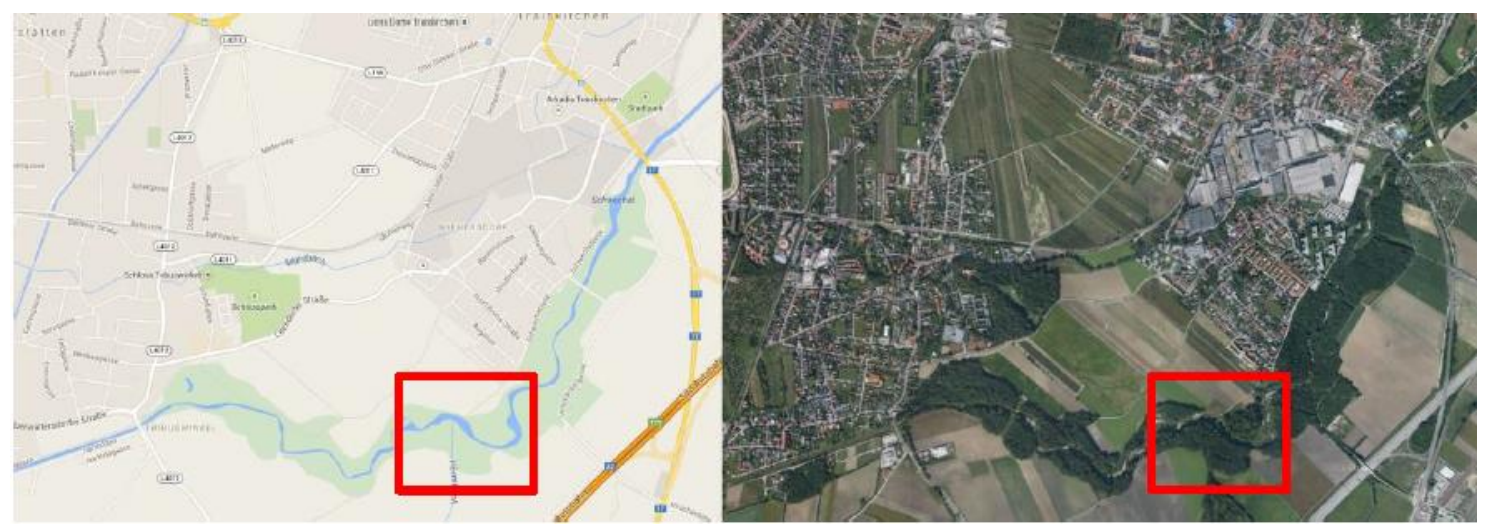

Figure 1. Study site at the Schwechat River. (Source: Google Maps)

The Wienerwald region is in the transition zone between the Pannonian climate in the east and the mainly oceanic swayed middle European climate in the west. The study area is located at about $200 \mathrm{~m}$ above sea level.

The summers are warm; the winters are very cold, dry, and windy; and it is partly cloudy year round. Over the course of the year the temperature reaches the annual average of about $12{ }^{\circ} \mathrm{C}$. The monthly mean minimum and maximum daily temperature of Baden district is presented in Figure 2.

The annual precipitation in this area is around $600 \mathrm{~mm}$ (2011) with minimum numbers in winter (February) and the maximum ones in summer (June and July). Figure 3 shows the average monthly rainy days over the year.

The perceived humidity level in Baden district, as measured by the percentage of time in which the humidity comfort level is muggy, oppressive, or miserable, does not vary significantly over the course of the year, staying within $2 \%$ of $2 \%$ throughout. The mean monthly relative humidity is displayed in Figure 4. All presented averages are based on weather reports collected during 2005-2015. 


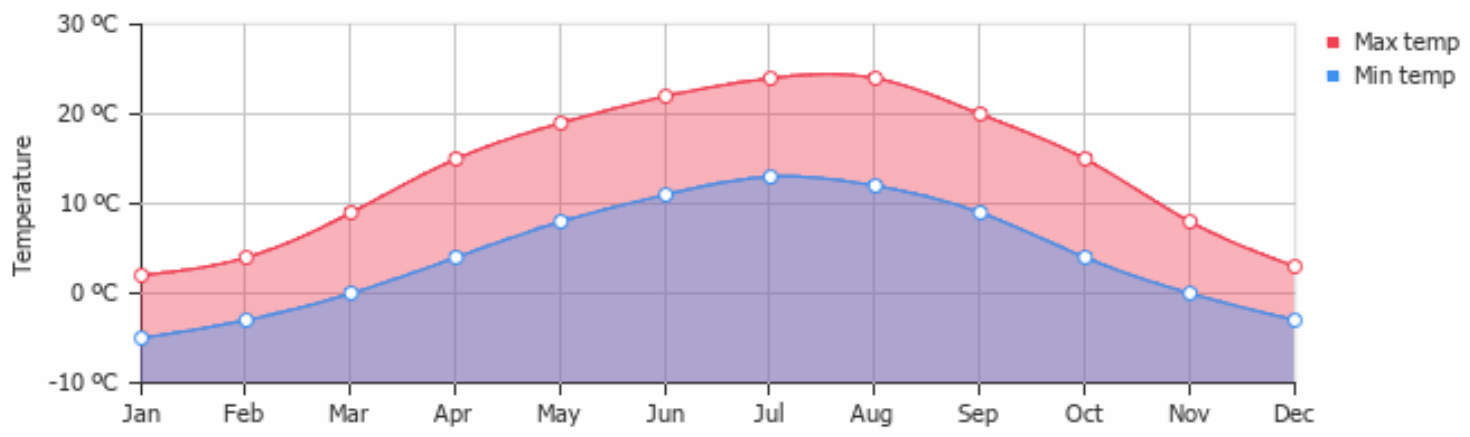

Figure 2. Monthly mean minimum and maximum daily temperature in Wiener Neustadt, Baden district. (Source: www.weather-and-climate.com)

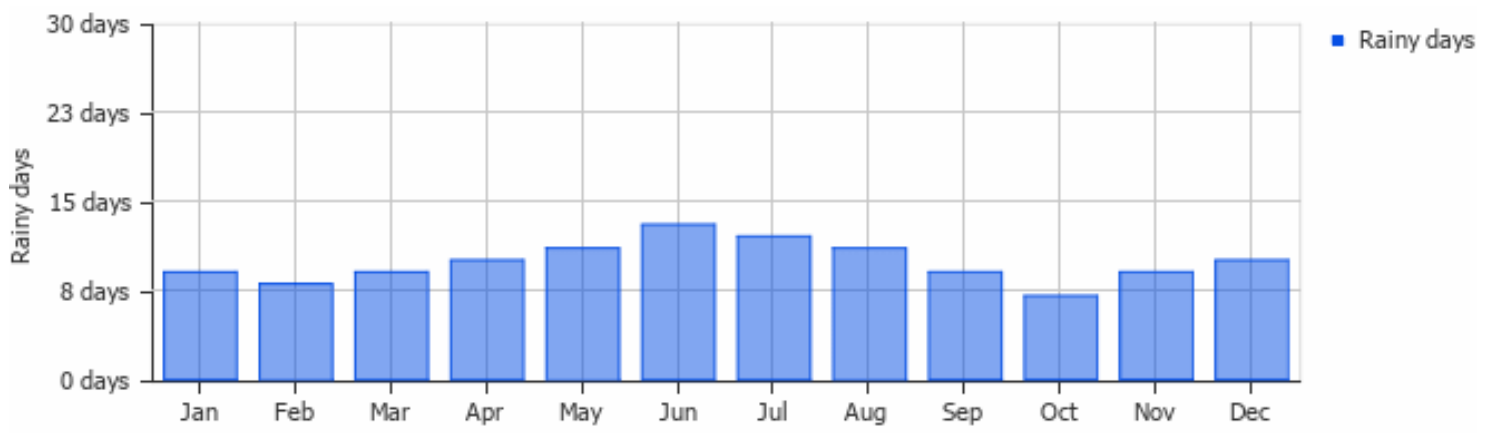

Figure 3. Average days with precipitation per month in Wiener Neustadt, Baden district.

(Source: www.weather-and-climate.com)

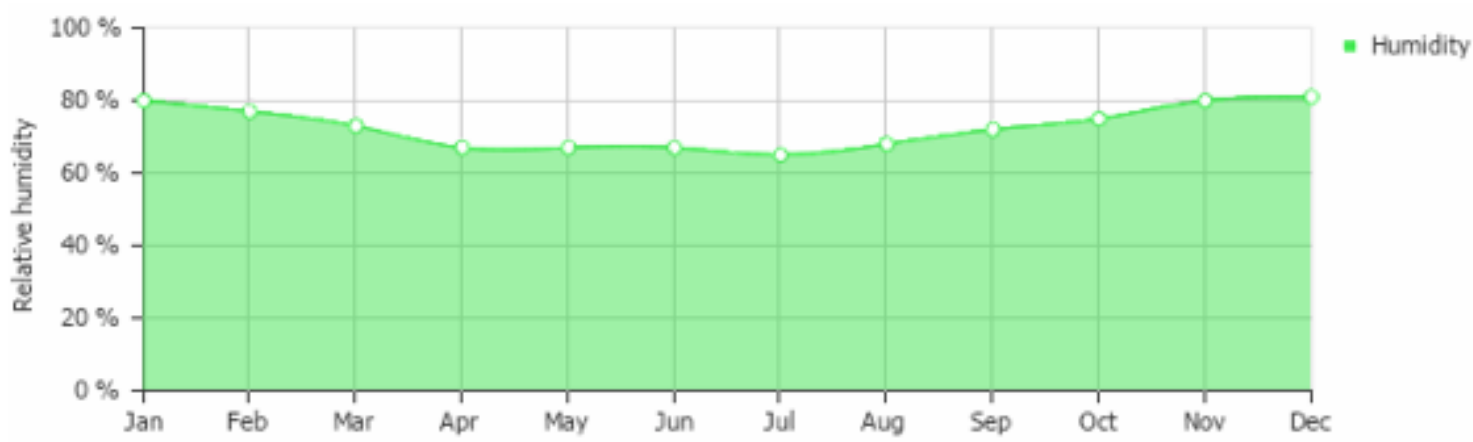

Figure 4. Average relative humidity in Wiener Neustadt, Baden district. (Source: www.weatherand-climate.com)

As the considered section for our research is close to the Traiskirchen the deciding discharge site is "Cholerakapelle" which is upstream of Baden. Table 1 shows recurrence intervals and correspondent discharges at this hydrological station. Run off data before and during the flood are displayed in Figure 5.

The flood occurred in May 2014 (peak May 16th, 2014). Maximum discharge that occurred during the flood was $91.7 \mathrm{~m}^{3} \mathrm{~s}^{-1}$ (http://ehyd.gv.at) which corresponds to the 4.5 year discharge. Historical maximum discharges are represented in Table 2. 

-6354 -

Table 1. Recurrence intervals and correspondent discharges. (Source: http://ehyd.gv.at)

\begin{tabular}{c|c}
\hline HQ & Discharge $\mathbf{Q}\left(\mathbf{m}^{\mathbf{3}} / \mathbf{s}\right)$ \\
\hline 100 & 260 \\
30 & 200 \\
10 & 140 \\
5 & 100 \\
2 & 53 \\
1 & 40 \\
MQ & 1.5 \\
\hline
\end{tabular}
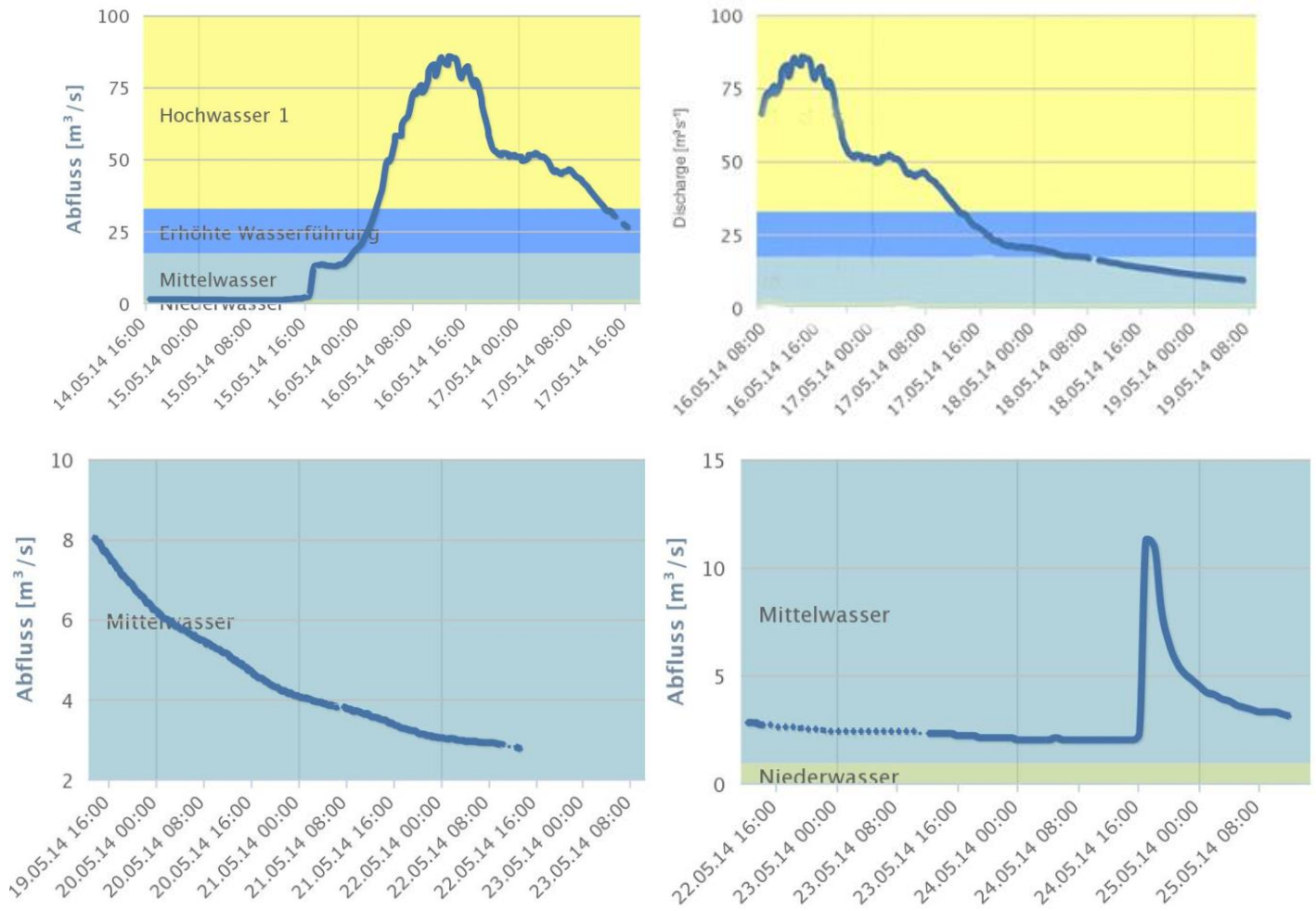

Figure 5. Run off data before and during the flood

Table 2. Historical maximum discharges. (Source: http://ehyd.gv.at)

\begin{tabular}{c|c|c|c}
\hline Date & $\mathbf{Q}\left(\mathbf{m}^{3} / \mathbf{s}\right)$ & $\mathbf{W}(\mathbf{c m})$ & x-year discharge \\
\hline 8.7 .1997 & 257 & 533 & 100 \\
1.7 .1975 & 150 & 412 & 12 \\
7.9 .2007 & 147 & 446 & 12 \\
8.8 .2006 & 143 & 443 & 10 \\
7.6 .2002 & 129 & 430 & 8.5 \\
13.8 .2002 & 106 & 408 & 5.5 \\
18.5 .1991 & 104 & 350 & 5.5 \\
16.5 .2014 & 91.7 & 394 & 4.5 \\
18.4 .1994 & 83.2 & 385 & 4 \\
9.2 .1987 & 65.1 & 302 & 3 \\
\hline
\end{tabular}




\section{Field measurements}

Observations were made along one transect (T1) located at River Schwechat; the transect was chosen appropriately to represent characteristics needed in this survey. Eight measuring plots within T1 transect were distinguished.

The research started in June and July 2013 when we determined the position of the transect and the measured plots. The comprehensive survey and field measurements of the floodplain vegetation continued in May and June 2014. Data measured in May 2014 were used to capture the transect state before the flood while data measured in June 2014 were used for defining the changes after the flood.

Plots were determined as areas of $2 \mathrm{~m} \times 2 \mathrm{~m}$, limited by using wooden removable frame (Fig. 6) fixed in one corner by an iron stake and three adjustable corners which were levelled using a spirit level. These frames were subdivided into a regular $0.2 \mathrm{~m}$ mesh defining 100 sampling subplots. Iron stakes driven into the substrate guided precise relocation of the plots, with starting position of $40 \mathrm{~cm}$ above the ground level. Each plot and its surroundings were documented by high-resolution photographs.

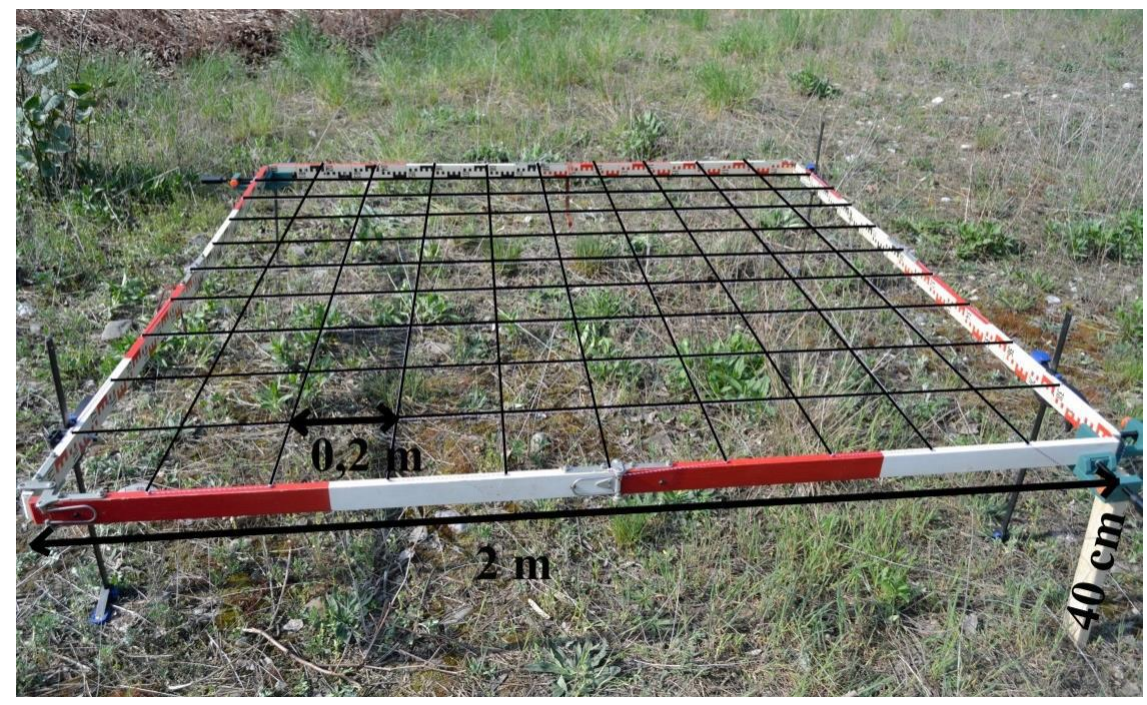

Figure 6. Frame design

The first step was to estimate total vegetation coverage in each plot followed by precise estimation in each subplot based on photographs. The key for the mapping units is based on the characterization of polygons in the aerial photo. The delimitation of the polygons with similar land cover was done before starting the mapping in the field. The data collection was focused on structural features. The dominant species and their coverage percentages were recorded. Furthermore, maximum plant height, median plant height, vegetation coverage and humus horizon thickness were measured in each subplot. Humus horizon thickness serves as a parameter to estimate amount of eroded/accumulated material, thus to estimate the changes of the humus horizon thickness.

The chosen study site is characterised by both a strong natural meandring and a high occurrence of wood and sediment transport during floods. Trees and debris that were transported during floods were deposited after stage decline and large areas with bare sand. Gravel banks were also observed. 


\section{Phytocoenological survey}

One of the most important part of the research was vegetation mapping provided by series of phytocoenological relevés which were conducted not only in the measured transect, but in the whole surrounding. That gave us quite clear idea about vegetation types present in the area of interest. As the riparian areas are considered to be valuable ecosystems because of their biodiversity and functions, part of our research was dedicated to the invasive species which can significantly lower the biodiversity and other important functions of these ecosystems.

Our phytocoenological research followed results of vegetation mapping obtained in Ecoriver project (Egger et al., 2013a). According to this project, 10 vegetation types were distinguished in the whole research area (Fig. 7).

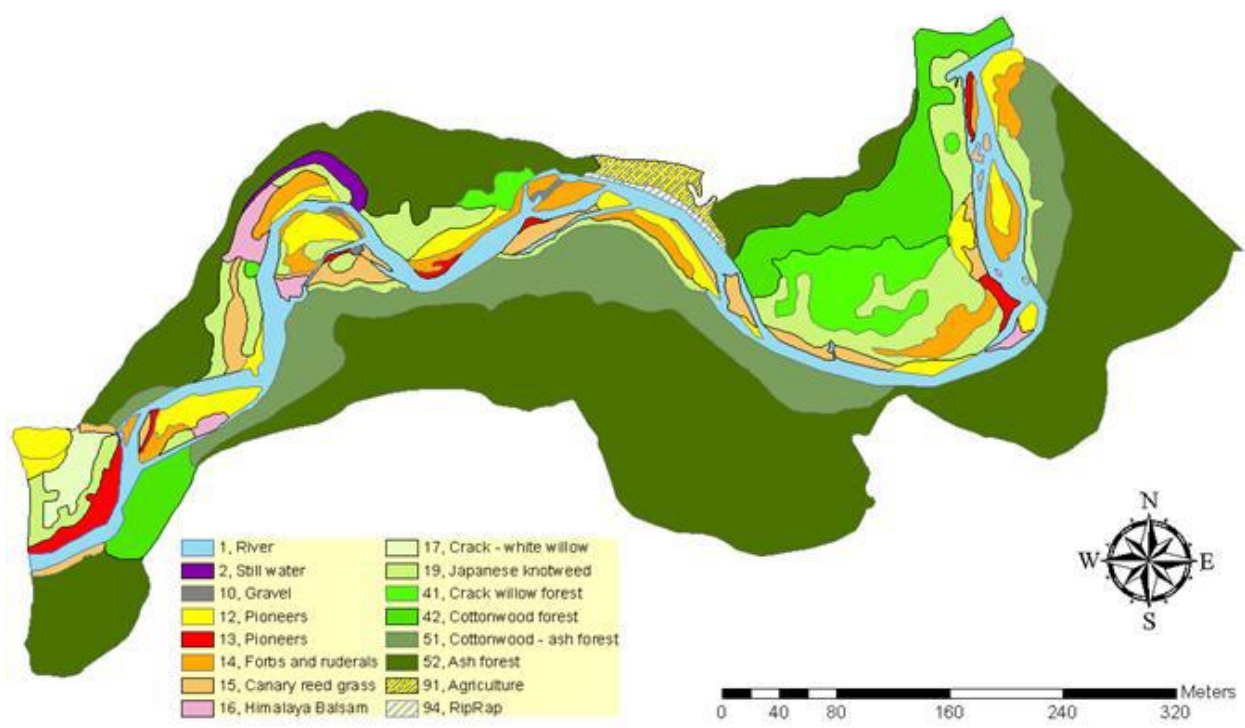

Figure 7. Mapped vegetation types. (Egger et al., 2013a)

Vegetation types were investigated by performing a phytocoenological relevés to define a floristic composition of these sites. Abundance of each plant species were classified according to the 7-points Braun-Blanquet classification (Braun-Blanquet, 1964). Nomenclature of plant taxa is presented according to the program TURBOVEG for Windows (Hennekens, 1998-2012). This computer software package was developed in The Netherlands for processing of phytocoenological data. The package comprises of an easy-to-use database management system. The data bank to be managed can be divided into several databases which may consist of up to 100.000 relevés each. The program provides methods for input, import, selection and export of relevés. In 1994, TURBOVEG was accepted as the standard computer package for the European Vegetation Survey. Currently it has been installed in more than 25 countries throughout Europe and overseas (Hennekens, 1998-2012). Relevés were used for defining the floristic composition of the site.

\section{Particle size survey}

Samples were taken from individual plots before the flood event (May, 2014). As the first step samples were dried and fine grained components were divided. Subsequently, 
saturated hydraulic conductivity was measured. Then the percentage of the different sized particles in each sample were determined using the Cassagrande densimetric method.

The areometric Cassagrande method is based on the use of special densimeters (areometers) that monitor changes in the density of a soil suspension in water and in various soil particle diameters in terms of the sedimentation time changes. Density changes are caused by the sedimentation process; the density of the hydro-suspension falls with the increasing length of measurement. This method is one of the non-repeated sedimentation methods, which means, that all of the measurements must be performed within one sedimentation process. An appliance for this method consisted of an analytical balance, porcelain dish, laboratory spoon, timer, calibrated cylinder $(1000 \mathrm{ml}$; Fig. 8), funnel, manual mixer, densimeter, thermometer, dispersing agent (sodium hexamethaphosphate) and distilled water.

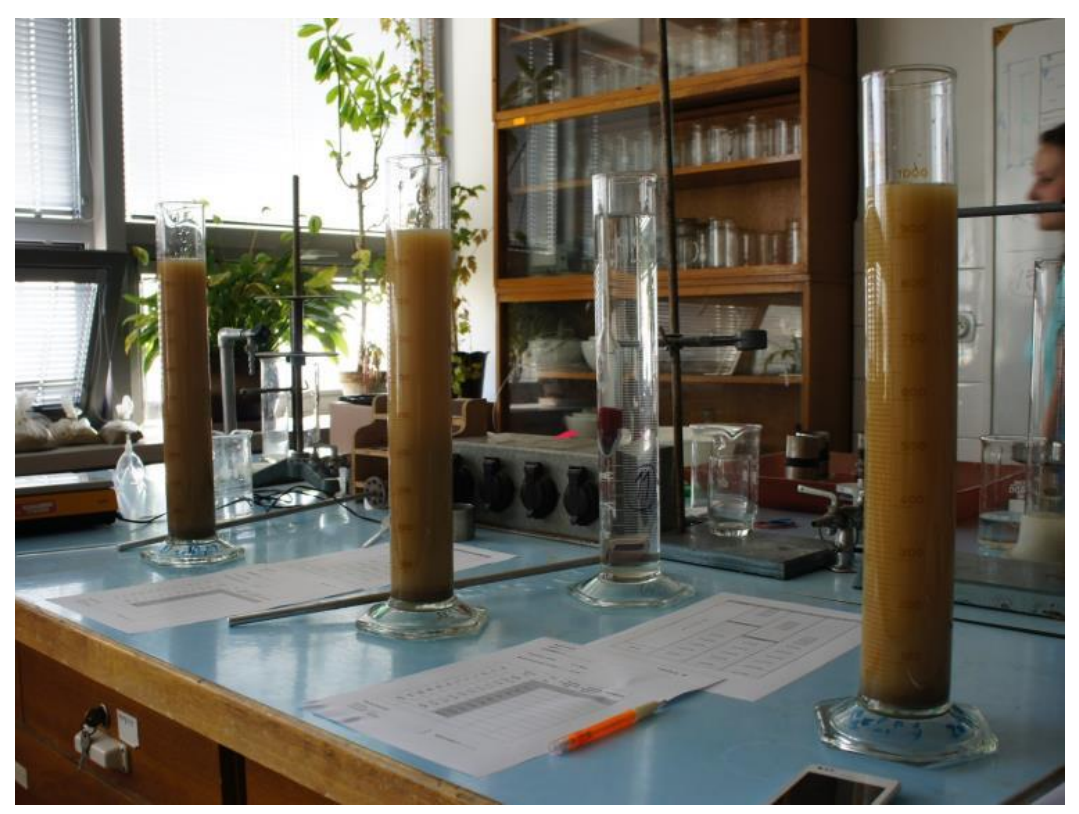

Figure 8. Calibrated cylinders $(1000 \mathrm{ml})$

The charge of fine grained soil differs according to the amount of clay particles in the soil. In the case of clayey soils, the charge ranges from 20 to $30 \mathrm{~g}$ (in clays it is $10 \mathrm{~g}$ ), as far as sandy-clay, loamy and clay-loamy soils are concerned, the charge is approximately $30-50 \mathrm{~g}$ and in case of sandy soils it is $100 \mathrm{~g}$. The soil was weighed, placed in a porcelain dish and mixed with distilled water $(200 \mathrm{ml})$. Dispersing agent was then added (10 ml of agent for every $10 \mathrm{~g}$ of fine grained soill) and was boiled for $1 \mathrm{~h}$. The suspension was mulled at the bottom of the dish after cooling while the muddy part was poured directly into a graduated cylinder $(1000 \mathrm{ml})$. The suspension in the graduated cylinder was mixed by a glass rod for one minute before the measurement started. When the glass rod was taken out, an areometer was put in its place and the first density measurement started after $30 \mathrm{~s}$.

The results were analysed with a nomogram in which the size of settling particles is determined depending on the individual sedimentation time. The process is followed by a percentual determination of individual fractions. 
The soil type was identified according to the given values based on the classification system used in Slovak Republic. It is being applied to particles with diameters below $0.01 \mathrm{~mm}$ (Table 3).

Table 3. Soil texture classification

\begin{tabular}{c|c|c}
\hline Particle content $<\mathbf{0 . 0 1} \mathbf{~ m m}(\boldsymbol{\%})$ & Soil type nomenclature & Basic soil type \\
\hline 0 & Sand & Light soil \\
$0-10$ & Sandy & \\
$10-20$ & Loamy sand & \multirow{2}{*}{ Medium heavy soil } \\
$20-30$ & Sandy loam & \\
$30-45$ & Loamy & Heavy soil \\
$45-60$ & Clayey loam & Clayey \\
\hline $60-75$ & Clay & \\
\hline 75 &
\end{tabular}

There were 8 measuring plots placed (T1-1, T1-2, T1-3 up to T1-8) in the evaluated transect. However, due to the huge development of invasive species stands (mostly by Fallopia japonica) it was not possible to measure all the parameters in three plots (T1-1, T1-2, T1-3) and they were not assessed.

\section{Statistical evaluation}

Similarly, due to the huge development of invasive species of Fallopia japonica it was not possible to measure all the parameters in three plots (T1-1, T1-2, T1-3) and they were not statistically evaluated. Therefore, data from 5 plots (T1-4 to T1-8) were evaluated, each plot was divided to 100 subplots $(0.2 \mathrm{~m} \times 0.2 \mathrm{~m})$, and in each subplot 4 parameters were measured. That makes 400 datasheets for each plot, altogether 2000 data for 5 evaluated plots. The relationships between parameters (dominant species and their coverage, maximum plant height, median plant height, vegetation coverage and humus horizon thickness) in the transect and also in the individual plots were analysed.

Fallopia japonica was quickly spreading after 2013, especially close to flood areas. That is why differences in the area of distribution were measured before and after flood. Measurements were performed in our area of interest.

\section{Hydraulic modelling}

The next step of our research was the modelling of the flood discharge from May 2014 using a MIKE 21 model together with Mud Transport Module (MT). Such module can simulate the processes of erosion, transport, setting and deposition in marine, brackish and fresh water areas. The module takes into account fine non-cohesive materials.

The aim of the hydraulic modelling was to find out the value of the shear stress, which was affecting the plots during the flood event. The model inputs were represented by the digital elevation model, which was created from the topographic data measured at the site, the flood characteristic discharges and the information about sediment character. The output of the model is the point mash with shear stress values. The output was exported to the GIS and used for creating graphic outputs of the modelling. 
The critical shear stress $\tau$ crit can be determined from the shields curve (Fig. 9). The shields curve presents the relation between non-dimensional critical shear stress and boundary Reynolds number $R e$ which is the Reynolds number on the interface between flowing water and surface. For higher Reynolds numbers the critical sheer stress decreases and for Reynolds numbers $R e>500$ the shields parameter is constant at 0.057 .

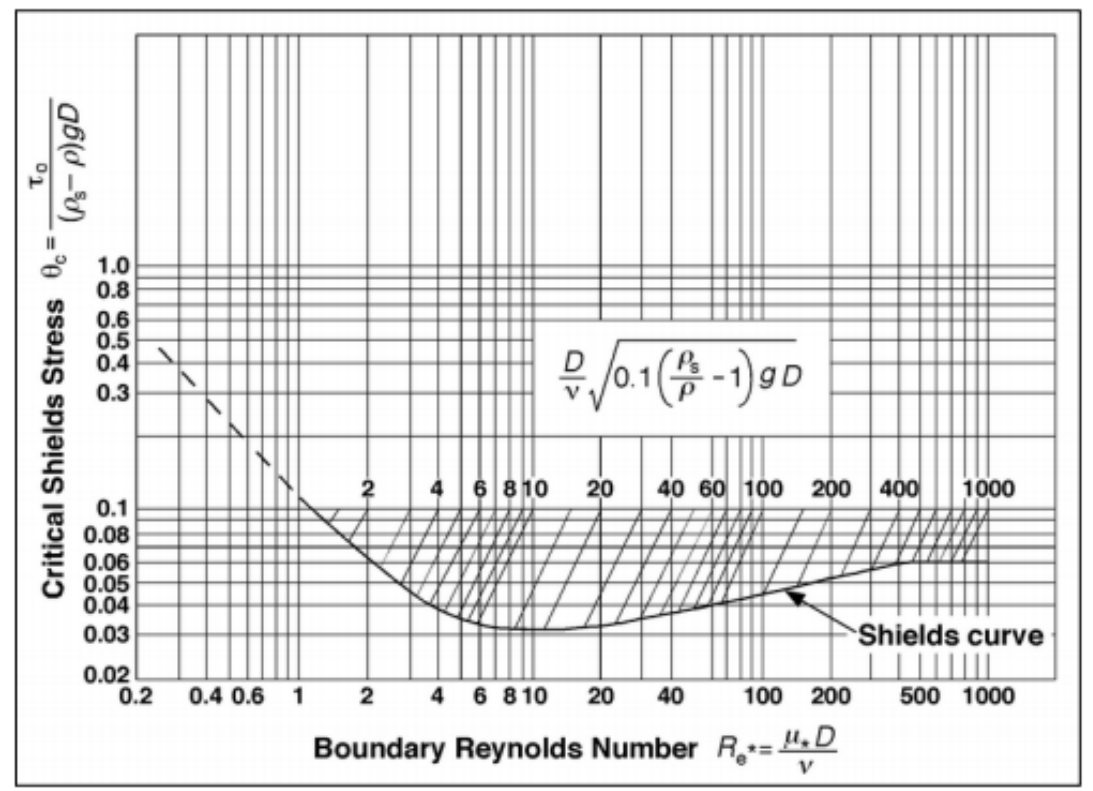

Figure 9. The shields curve

\section{Results}

\section{Phytocoenological survey of distinct vegetation types}

Phytocoenological characterization was performed in order to distinguish all the vegetation types present in the surroundings of $\mathrm{T} 1$ transect. Only herb vegetation occurred in the area of transect therefore the effect of herb vegetation on the erosion sedimentation processes are presented. Hopefully research will continue in the future, when there will be more localities and effect of woody vegetation evaluated, so the research can follow by characterization of the vegetation presented in this study.

Pioneer site at the transect is typically dominated by species of Saponaria officinalis usually followed by species of Chenopodium album, Echium vulgare, Impatiens glandulifera, Melilotus officinalis, Papaver rhoeas, Persicaria dubia, Phalaris arundinacea, Poa pratensis, Arctium sp., Polygonum aviculare and young tree seedlings of Populus $x$ canadensis and Salix fragilis. The second type of pioneer site is dominated by species of Impatiens glandulifera, subdominated by Saponaria officinalis or Urtica dioica following with species like Echium vulgare, Galium aparine, Phalaris arundinacea, Artemisia vulgaris, Hedera helix, Melilotus album, Plantago lanceolata, P. major and Poa pratensis.

Closer to the poplar forest edge a pioneer site dominated by seedlings of young Populus nigra trees with few individuals with shrub height were found, sometimes subdominated in herb and also in shrub layer by tree species of Robinia pseudoacacia 
followed by species Phalaris arundinacea, Saponaria officinalis, Urtica dioica and Plantago major, Hedera helix, Chelidonium majus, Ulmus laevis.

There were three types of forbs and ruderals stands in our study site - the first one dominated by Echium vulgare and/or Arrhenatherum elatius (on the drier stands), the second one dominated by Impatiens glandulifera and the third type of forbs and ruderals is dominated by Phalaris arundinacea.

Wetter type of forbs and ruderals are stands dominated by Phalaris arundinacea often followed by Urtica dioica, typical are also young poplar and willow trees in herb or shrub layer, also Saponaria officinalis with higher abundance. Among other species found here were for example Impatiens glandulifera, Rumex obtusifolius, Juglans nigra, Lapsana communis, Lolium perenne, Scrophularia umbrosa, Lythrum salicaria, Stellaria sp., Mentha longifolia, Taraxacum sect. Ruderalia, Petasites hybridus, Trifolium hybridum.

There were just few localities with crack-white willow stands in our study area and they had small coverage. Tree layer is formed by Salix fragilis, S. alba, Robinia pseudoacacia. Shrub layer is typically covered by Fallopia japonica that is present also in herb layer together with Impatiens glandulifera. Few patches with the crack willow forest were found at the site with Salix fragilis species. Vitis vinifera was typical in tree, shrub and also in herb layer. This site has typical shrub layer in crack willow stands, because in most cases it invaded by Fallopia japonica that is typical also in herb layer.

Large stands of poplar forest vegetation type were not found so it was possible to put together only one phytocoenological relevé. There was significant dominance of poplar trees in the low tree layer followed with Fraxinus excelsior, Acer platanoides, Ulmus minor, Acer campestre, Acer negundo, Prunus avium and Prunus padus. Shrub layer was dominated by Sambucus nigra and also species of Cornus sanguinea, Juglans regia, Ulmus minor, Fallopia japonica, Prunus padus and Corylus avellana were found here. Herb layer was dominated by species of Aegopodium podagraia with Urtica dioica, Alium ursinum and Galeobdolon luteum.

Poplar - ash forest occured in both higher and lower tree layers with dominant species of Fraxinus excelsior, Populus nigra, Acer campestre, Acer platanoides, Ulmus minor, Ulmus laevis, Robinia pseudoacacia and Juglans nigra. Shrub layer was represented by Cornus sanguinea, Acer platanoides, Acer campestre, Crataegus monogyna, Sambucus nigra, Ulmus minor, Ulmus glabra, Cornus mas, Juglans regia, Ligustrum vulgare and Acer negundo. Herb layer was dominated by Lonicera xylosteum and subdominated by Aegopodium podagraria. All the above mentioned species from tree and shrub layers can also be found in herb layer together with species of Salvia glutinosa, Knautia arvensis, Arum maculatum, Rubus caesius.

Typical maple species in higher tree layer were represented by Acer campestre, A. platanoides and $A$. negundo, ash Fraxinus excelsior was dominant in lower tree layer where also Populus alba, Ulmus laevis Tilia platyphyllos and less Ulmus minor, Prunus padus were found. Shrub layer is also formed by these tree species and seedlings were also found in the herb layer. Typical shrub species in these forests are Sambucus nigra, Ligustrum vulgare, Acer campestre, Ulmus minor, Crataegus monogyna, Rosa canina, Cornus sanguinea, Juglans regia, Fraxinus excelsior. In herb layer a presence of Lonicera xylosteum, Aegopodium podagraria, Hedera helix, Allium ursinum were noticed as well as species like Arrhenatherum elatius, Arum maculatum, Calystegia sepium, Chenopodium bonus-henricus, Elymus caninus, Euonymus europaeus, Rubus caesius, Ranunculus repens, Polygonatum latifolium and seedlings of tree species. 
Phytocoenological relevés were performed in the surroundings of the measured plots (not directly at plots measured) in order to have a better picture of phytocoenological composition of the transect surroundings. Relevés were used for defining the floristic composition of the site. The example of phytocoenological table with releve is presented in the phytocoenological Tables 4 and 5.

Table 4. Phytocoenological table. R1., R2., R3. - Impatiens glandulifera; R4., R5. - Phalaris arundinacea

\begin{tabular}{|c|c|c|c|c|c|}
\hline Species & $\begin{array}{l}\text { Relevé } \\
1 .\end{array}$ & $\begin{array}{l}\text { No. } \\
2 .\end{array}$ & 3. & 4. & 5. \\
\hline \multicolumn{6}{|l|}{ Shrub layer } \\
\hline Salix fragilis & & . & & 1 & . \\
\hline \multicolumn{6}{|l|}{ Herb layer } \\
\hline Raminculus repens & & . & & + & . \\
\hline Impatiens glandulifera & 4 & 3 & 4 & + & $r$ \\
\hline Phalaris arundinacea & 3 & 2 & 2 & 3 & 4 \\
\hline Plantago major & + & & . & & . \\
\hline Saponaria officinalis & 1 & + & 3 & 1 & + \\
\hline Urtica dioica & 2 & 1 & 3 & 3 & 1 \\
\hline Clematis vitalba & & & + & + & \\
\hline Fallopia japonica & & . & + & . & . \\
\hline Hedera helix & & & + & & . \\
\hline Poa nemoralis & & . & $r$ & . & . \\
\hline Populus nigra & & . & $\mathrm{r}$ & 2 & . \\
\hline Robinia pseudacacia & & . & 1 & . & . \\
\hline Lolinum perenne & & . & & + & . \\
\hline Melilotus albus & & 1 & & . & \\
\hline Arctium species & & . & & . & 1 \\
\hline Artemisia vulgaris & & & & 2 & . \\
\hline Plantago lanceolata & & . & & + & . \\
\hline Sisymbrium strictissimam & & r & & . & . \\
\hline Anthemis arvensis & & . & & 1 & \\
\hline Arctoa species & & . & & + & . \\
\hline Barbarea vulgaris & & & & + & . \\
\hline Juglans nigra & & . & & $\mathrm{r}$ & . \\
\hline Lapsana communis ssp. communis & & & & $r$ & . \\
\hline Lythrum salicaria & & r & & + & + \\
\hline Mentha longifolia & & & & + & \\
\hline Petasites hybridus & . & & . & + & . \\
\hline Poa trivialis & & . & & 1 & . \\
\hline Populus alba & & & & $\mathrm{r}$ & + \\
\hline Rumex crispus & & . & & r & + \\
\hline Rumex obtusifolius & & & & + & . \\
\hline Scrophularia umbrosa & . & & . & $r$ & . \\
\hline Stellaria species & & . & & $\mathrm{r}$ & . \\
\hline Taraxacum sect. Ruderalia & . & & . & r & . \\
\hline Trifolium hybridum & & . & & r & . \\
\hline Elymus canimus & . & & . & $\mathrm{r}$ & . \\
\hline Fallopia convolvulus & & . & . & & + \\
\hline Persicaria species & . & . & & . & + \\
\hline Poa palustris & & . & . & & 1 \\
\hline Salix purpurea & . & - & & . & r \\
\hline Setaria pumila & & . & . & & + \\
\hline
\end{tabular}


Table 5. Phytocoenological table header $(R 1-R 5)$

\begin{tabular}{lcclcl} 
Relevé number & $\mathbf{l .}$ & $\mathbf{2 .}$ & $\mathbf{3 .}$ & $\mathbf{4 .}$ & $\mathbf{5 .}$ \\
\hline Date (year/month/day) & $2013 / 07 / 26$ & $2013 / 06 / 15$ & $2013 / 07 / 26$ & $2013 / 06 / 16$ & $2013 / 07 / 18$ \\
Relevé area (m2) & 10.00 & 4.00 & 12.00 & 16.00 & 16.00 \\
Cover total (\%) & 95 & 40 & 80 & 95 & 85 \\
Cover shrub layer (\%) & 0 & 0 & 0 & 4 & 0 \\
Cover herb layer (\%) & 95 & 40 & 80 & 95 & 85 \\
Height shrub layer (m) & 0.0 & 0.0 & 0.0 & 1.7 & 0.0 \\
Height herb layer (cm) & 110 & 40 & 130 & 100 & 70 \\
Max. height herb layer & & & & & \\
(cm) & 140 & 160 & 150 & 170 & 100 \\
Richness & 5 & 7 & 10 & 28 & 14 \\
Shannon & 1.08 & 1.17 & 1.53 & 2.41 & 1.31 \\
Evenness & 0.67 & 0.60 & 0.66 & 0.72 & 0.50 \\
Simpson & 0.59 & 0.56 & 0.73 & 0.84 & 0.48
\end{tabular}

\section{Particle size survey}

Particle size survey was performed in the laboratory, The Casagrande's method was used for evaluation (Table 6) of 5 samples, each representing one plot (T1-4 to T1-8). Based on our field measurements performed in 2014, 3 plots (T 1-1, T 1-2 and T 1-3) were not assessed due to the presence of Fallopia japonica.

From the particle size analysis shown in Table 6 the soil types in each of our measured plots can be characterized The amount of the sand in the samples is greatest in the last two plots T1 -7 and T1-8.

Table 6. Particle size analysis

\begin{tabular}{l|l|l|l|l|l} 
Particles & T1-4 & T1-5 & T1-6 & T1-7 & T1-8 \\
\hline Silt (\%) & $<1$ & $<1$ & 6 & $<1$ & $<1$ \\
\hline Clay (\%) & 16 & 21 & 23 & 6 & 7 \\
\hline Clayic sand (\%) & 8 & 9 & 2 & 2 & 1 \\
\hline Sand (\%) & 76 & 70 & 69 & 92 & 92
\end{tabular}

\section{Statistical evaluation}

Analysis of the relationships between individual parameters consisted of the evaluation in the whole transect and within the plots using the linear regression analysis. Data were obtained in May 2014 in two different time periods. The status before and after flood had to be compared as it was necessary to find out the effect of the vegetation on soil during flooding. Flood was culminating on May 16th, 2014 and it was not possible to get to the transect because of the flooded access, Figures 10 and 11 represent localities upstream and downstream from the research site. Data from 5 plots in T1 transect (T1-4 to T1-8) have been evaluated and, also, analyses of individual 
parameters dependence on the channel distance and dependence of humus horizon difference on the vegetation parameters (height, coverage) were performed.

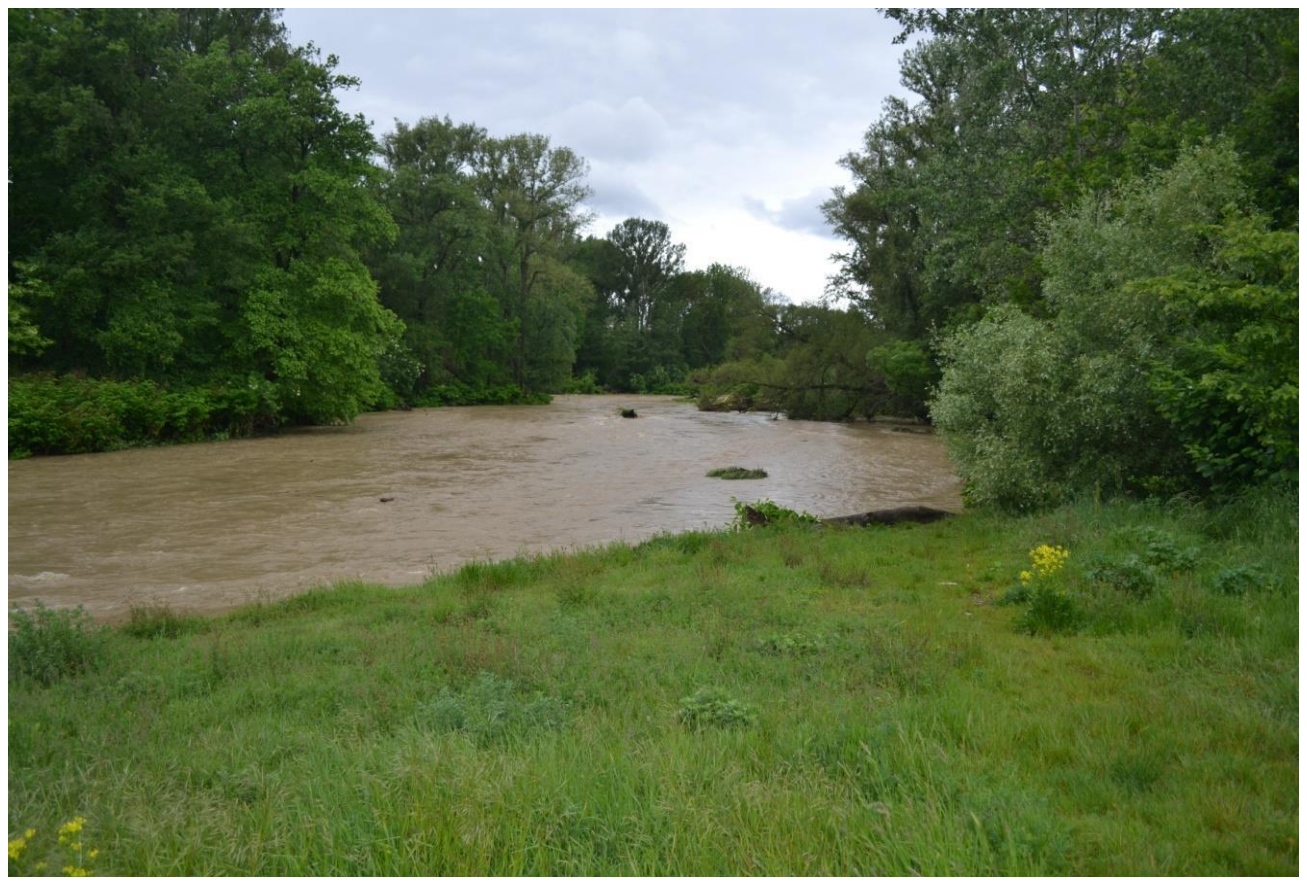

Figure 10. Flood - downstream

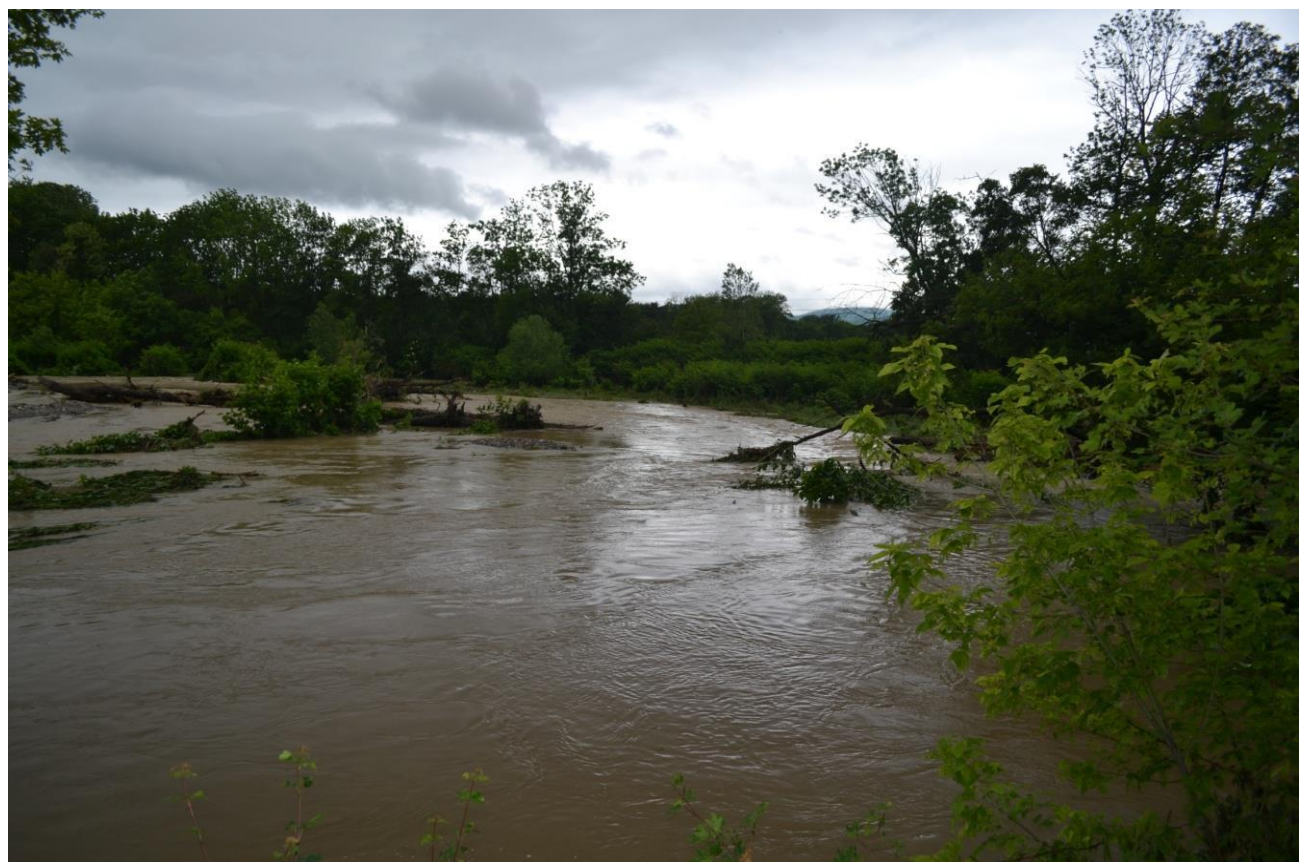

Figure 11. Flood - upstream

The graph and the regression line of the dependence between vegetation coverage and the distance from the water body is presented in Figure 12. Correlation coefficient is negative and equals to -0.542 , reflecting strong negative relationship between these 
two parameters. This value means that with the increasing distance from the water, vegetation coverage is getting lower in the area within 12-30 m distance from the water body.

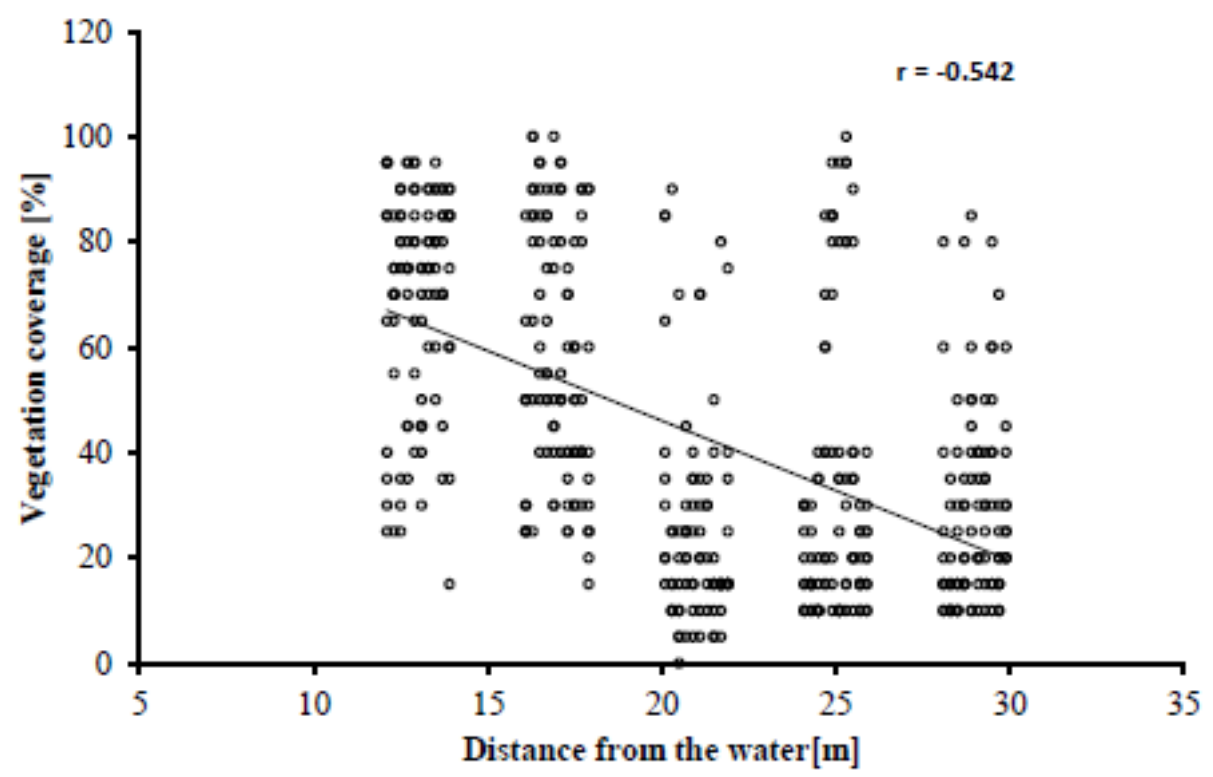

Figure 12. Dependence of the vegetation coverage on the distance from the water body

In Figure 13 the graph of the dependence of the maximum plant height and the distance from the water body is presented. Similar results to the one in the previous case were observed; correlation coefficient is negative and equals -0.454 . This value can be interpreted as a strong negative relationship between variables. We can conclude, that in the plots T1-4 to T1-8, the greater is the distance from the river the lower is the maximum plant height.

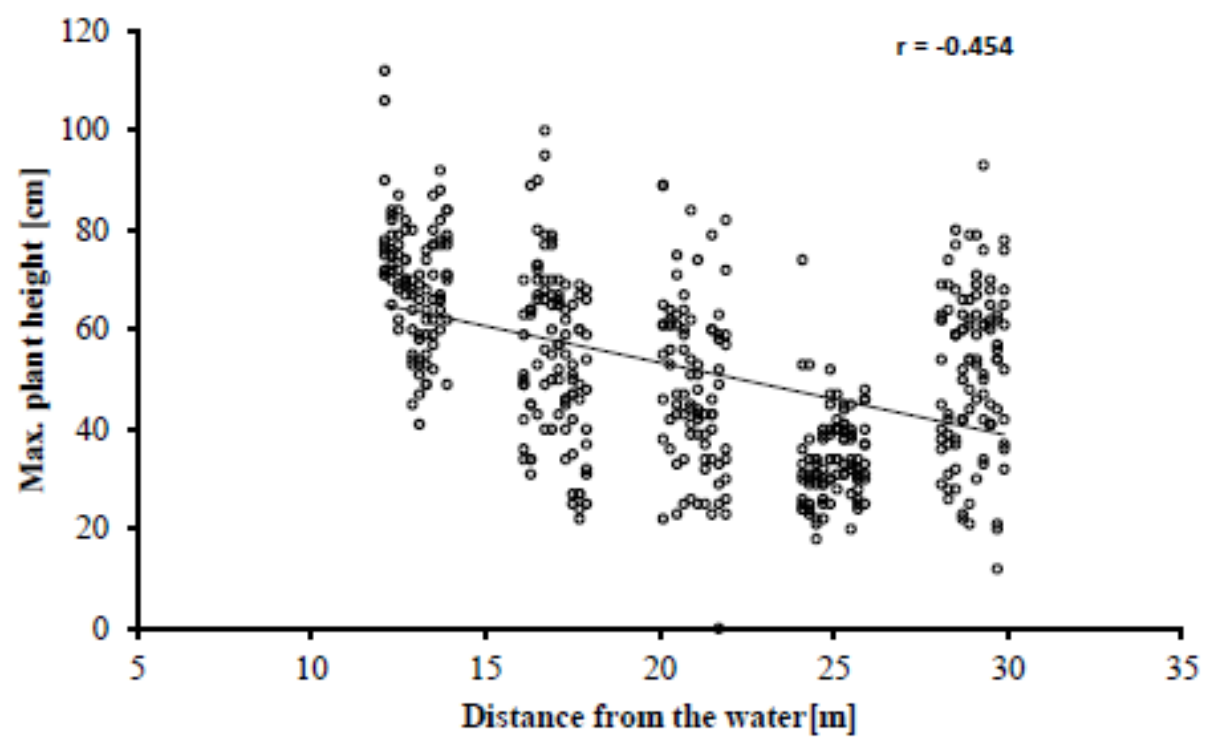

Figure 13. Dependence of the maximum plant height on the distance from the water body 
Figure 14 shows dependence of the humus horizon thickness difference (difference before and after flood) and distance from the water body. In this case, the correlation coefficient result was a positive value equal to 0.779 . This value reflects positive relationship; with greater distance from the river the humus horizon thickness difference is increasing. Erosion is decreasing and deposition of material is starting to occur with increased distance from the water body. In this case, the effect of the distance from the river on the changes in the humus horizon thickness is more important than other measured vegetation parameters (height, coverage).

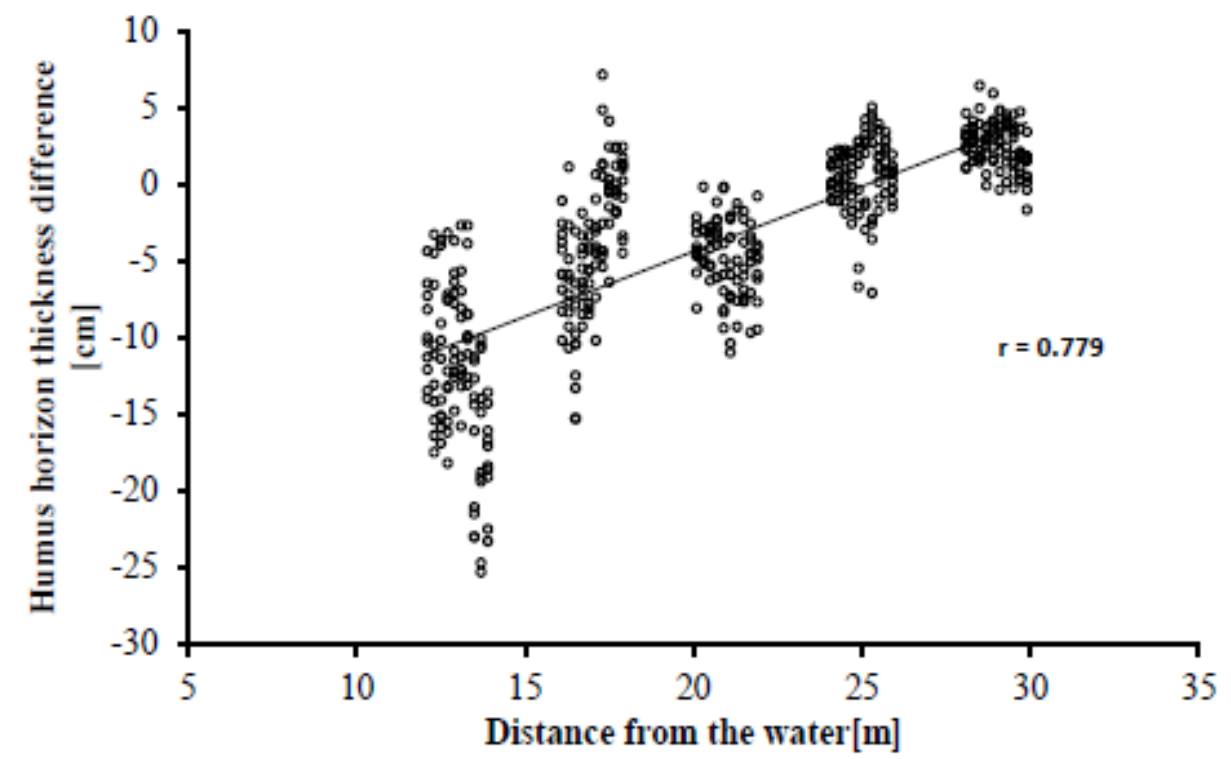

Figure 14. Dependence of the humus horizon thickness difference on the distance from the water body

Figure 15 shows dependence between maximum plant height and vegetation coverage. Correlation coefficient value is $r=0.5$ and it can be concluded that there is a positive correlation between these two parameters; value of the maximum plant height is increasing with increased vegetation coverage.

In Figures 16 and 17 relationships between humus horizon thickness differences and vegetation parameters; vegetation coverage and maximum plant height are presented. In both cases the correlation coefficient had negative values $(-0.498$ a 0.471) reflecting negative relationship between variables. It can be concluded that with higher percentage of vegetation coverage in measured plots the erosion in humus horizons of fluvisols increased and the deposition decreased. Similar conclusion can be confirmed for plant height; erosion is higher with higher maximum plant height.

The above presented results show that distance from the water body was the most important effect on the thickness of the humus horizon in fluvisols at the chosen site. Taking into account the conditions during flood event in spring 2014, the vegetation did not have such important role. It must be noticed that we are dealing with a complex system and complicated process, thus other involved factors (e.g. species composition, size of the root system, roughness of the vegetation cover) were not considered in this study. 


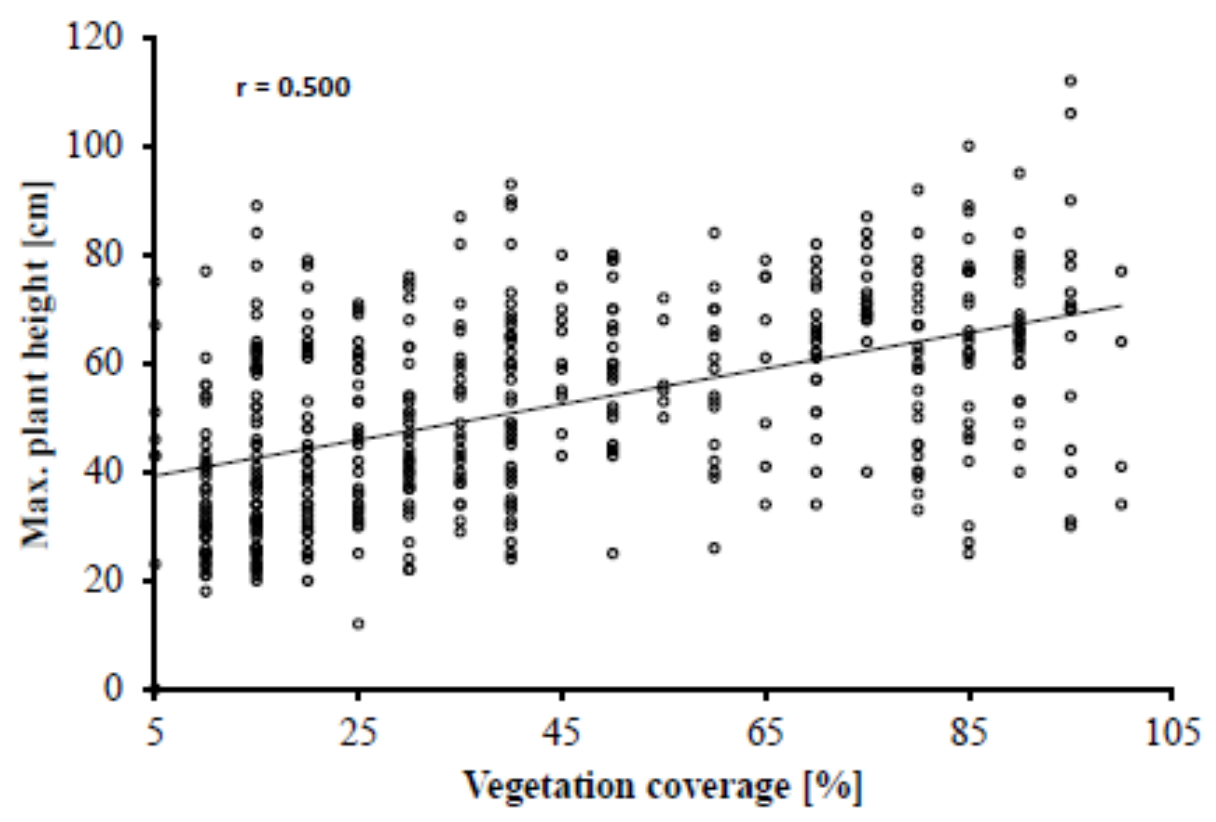

Figure 15. Dependence of the maximum plant height and the vegetation coverage

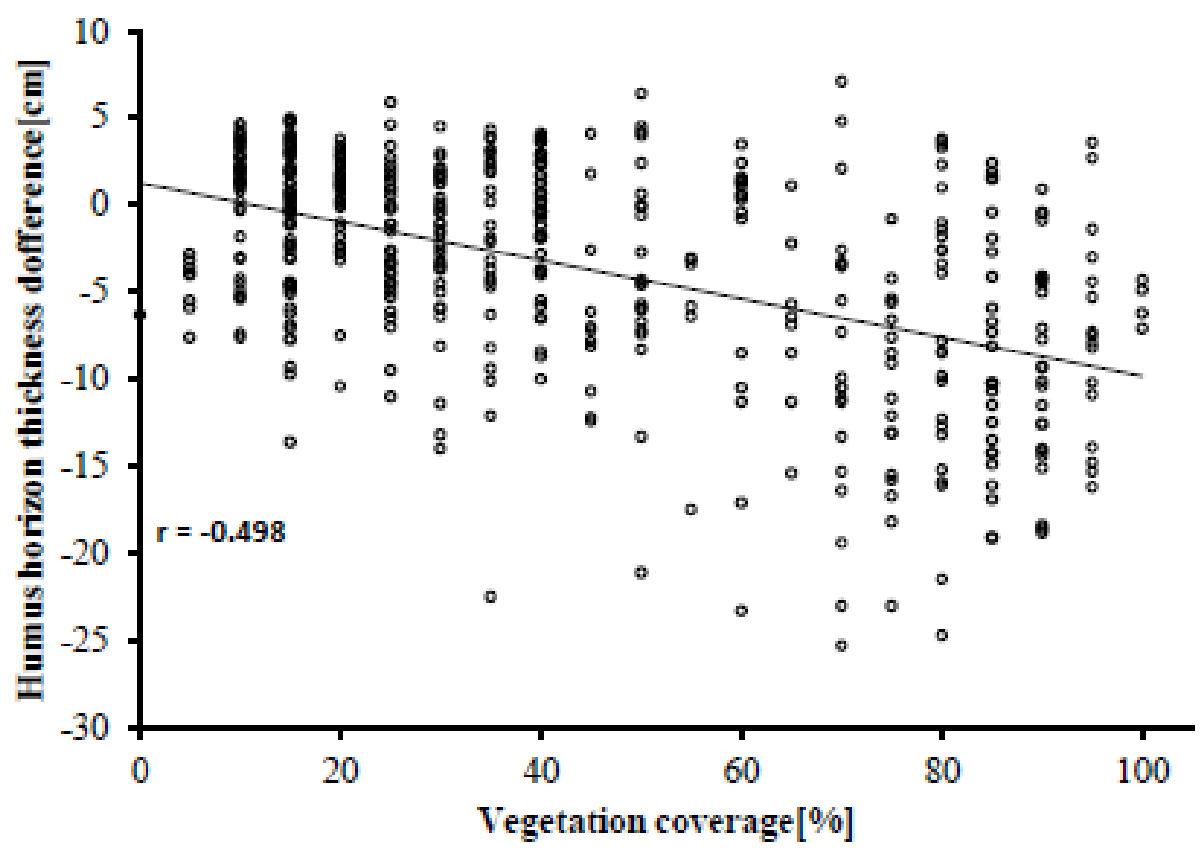

Figure 16. Dependence of the humus horizon thickness difference and the vegetation coverage

Our results of the relationship analysis between vegetation characteristics and changes in the humus horizon thickness are in contradictions with the published information. Surprisingly, there are mainly negative correlations between the change in the thickness of humus horizon and vegetation coverage, respectively maximum plant height. The results indicate, that vegetation promote erosion and negatively affect sediment accumulation. Such correlation relationships apparently cannot be a causal relationship but it is only a seeming correlation. Effect of vegetation in the studied 
riparian zone is masked by the influence of spatial change of vegetation characteristics. In the matter of fact, very strong negative correlation was recorded for the relationship between the distance from the water body and vegetation coverage, respectively maximum plant height.

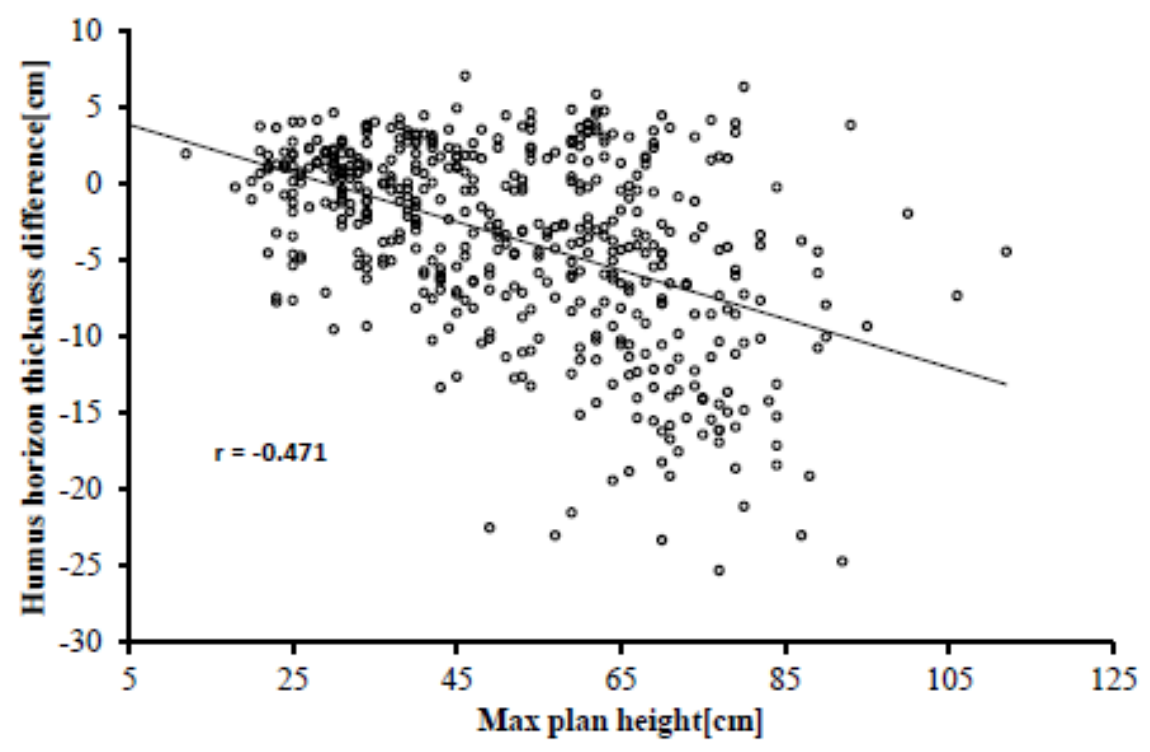

Figure 17. Dependence of the humus horizon thickness and maximum plant height

\section{Hydraulic modelling}

Shear stress was modelled using MIKE21 processed in the GIS environment; Figure 18 represents the output from model with shear stress values for whole area while Figure 19 shows the shear stress values simulated for individual plots. The highest values of shear stress were simulated in the T1-4 and T1-5 plots, in the plot T14 shear stress values were equal to $19 \mathrm{~N}^{-2} \mathrm{~m}^{-2}$ and in the plot T1-5 there were equal to $17 \mathrm{~N} . \mathrm{m}^{-2}$. During flooding of such intensity (app. Q4.5), the humus horizon is eroded in the area of these plots. The plot T1-6 appeared to be a "transition zone" between erosion and sedimentation, shear stress values were equal to $16-9 \mathrm{~N} \cdot \mathrm{m}^{-2}$ and humus horizon sinked to minimal values.

\section{Discussion}

River channel significantly changes during the flood. The influence of vegetation on the channel transport and dynamics was analysed in few studies (Gurnell, 2014, 2016a, b; Rinaldi et al., 2013, 2015). It can be concluded that vegetation plays significant role in shaping the river channel and morphodynamic river development (Liu and Neph, 2016). Presence of vegetation causes that with lowering the velocity flow the shear stress is lowering and the river bank is stabilizing.

There are few types of erosion occurring around the river during the floods, while thanks to the surface erosion; also plants can be eroded together with soil particles (Rivaes et al., 2014).

Surface erosion can be found on bigger areas closer to the channel, with evenly distributed, high shear stress on the surface. 


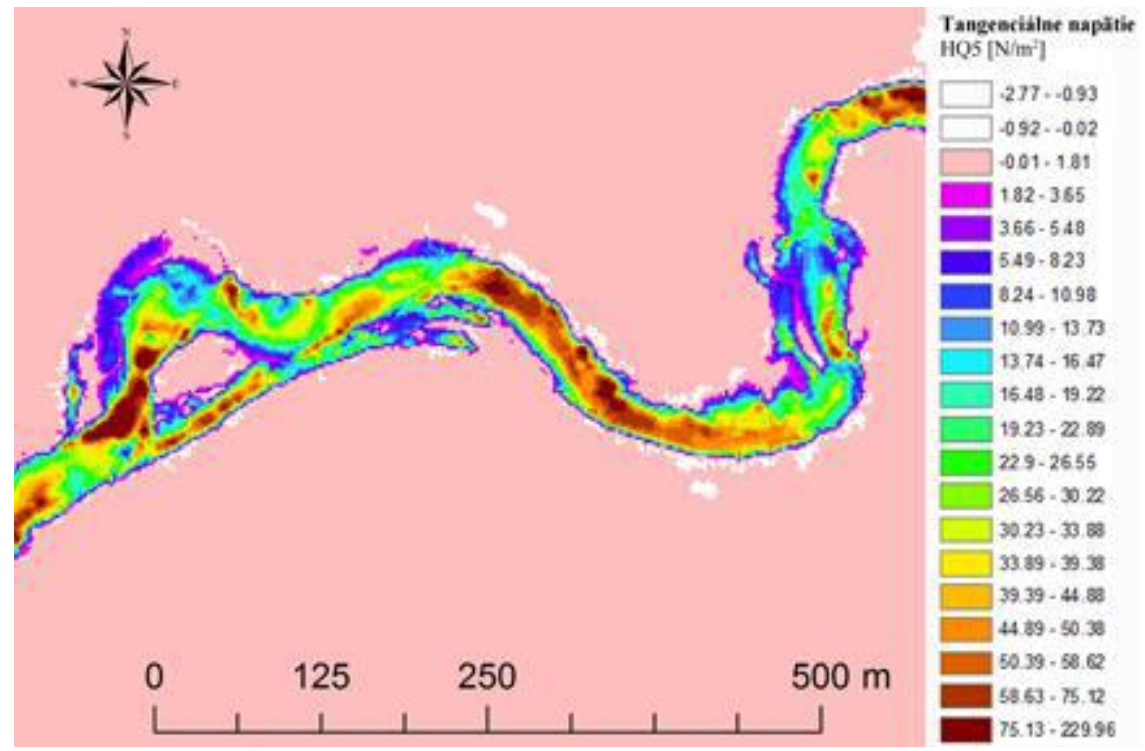

Figure 18. Modeled shear stress in the evaluated plots of the Schwechat River Q 4,5 (Arc Map)

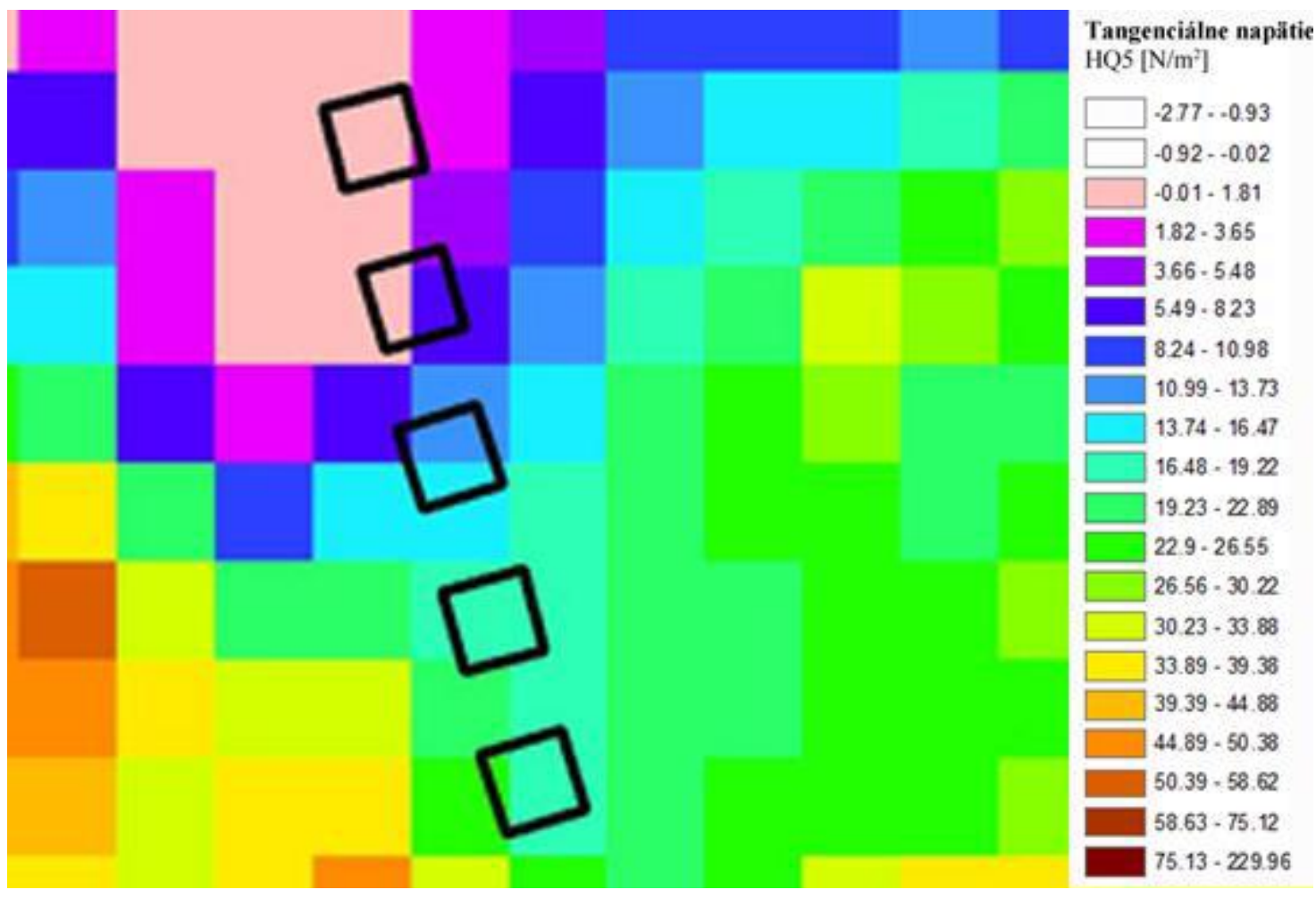

Figure 19. Modelled shear stress in the evaluated plots of the Schwechat River $Q 4,5$

Aforementioned studies proved that vegetation, according to its lowering of the flow velocity and the shear stress values, has a significant anti-erosive function. Presence of the vegetation can also support deposition of sediments and cohesive particles brought by water during the floods.

As already mentioned, our results of the relationship analysis between vegetation characteristics and changes in the humus horizon thickness are in contradictions with 
the published information. Surprisingly, there are mainly negative correlations between the change in the thickness of humus horizon and vegetation coverage, respectively maximum plant height. Effect of vegetation in the studied riparian zone is masked by the influence of spatial change of vegetation characteristics. In the matter of fact, very strong negative correlation was recorded for the relationship between the distance from the water body and vegetation coverage, respectively maximum plant height.

As shown by shear stress modelling, changes in the thickness of humus horizons are influenced mainly by a significant decline in the values of shear stress exerted by water during flood events on the soil surface. The sharp decline in shear stress with increasing distances of the water flow has resulted in a gradual shift from erosion processes with a negative change in the thickness of humus horizons, to the accumulation process with a positive change in the thickness of the research areas furthest from the water flow. The impact of changes shear stress on erosion-accumulative processes in the studied area is in addition highlighted by the spatial variation of grain composition of soils. Since with increasing distance from the water flow is the proportion of the lighter particles in the soil lowering, and on the other hand the proportion of heavier sand particles is increasing. The impact of this physical process is so powerful that it completely obscures the effect of vegetation present in the research plots, resulting in the aforementioned correlation relations.

\section{Conclusion}

The main aim of this research was to find out how important is the influence of vegetation in floodplain areas on deposition and erosion of the sediment, thus on the thickness of the humus horizon during floods. In the selected site of the river Schwechat in Lower Austria we observed different parameters required for this analysis. Among many data, those that meet the objectives of our study were selected and these were also statistically evaluated.

Statistical evaluation had two stages; the first step was to evaluate the variability across the transverse profile, the second step was to evaluate variability in individual squares - plots. In this case, we can conclude, that the variability within the plots was not as significant; thus, the distance between the pads within a square were not big enough to be able to see any significant difference in the effects of various parameters on the thickness of the humus layer.

From the evaluated data it was obvious that on the T1-4 plot erosion of sediment during the flood originally appeared, but that decreases with a distance from the shore and is changing to sedimentation on the plots T1-7 and T1-8. The role of the statistical evaluation was to determine which factors have the greatest impact on erosion accumulative processes affecting the variations in thickness of humus horizons of fluvisols. The investigated factors on the results of field research were especially distance from the water flow and the plants height and vegetation coverage. There were also modelled values of shear stress exerted by water on the soil surface during flood events.

Trying to characterize a specific process of such a complex system is certainly a difficult task and we have to keep in mind that the thickness of humus horizon of fluvisols in the offshore area is affected by many more factors, which was not taken into account in this work; such as the nature of vegetation, its detailed species composition 
and distribution, folic coverage, the coverage and the nature of the root system of vegetation.

Unfortunately, it was not possible to evaluate all the selected transect areas as it was not possible to collect data for the amount of sediment during the second measurement thanks to massive distribution of species Fallopia japonica. The selected plots with complete data provide characteristics for remote area 16 to 40 meters from a watercourse, with predominantly sandy-loamy to sandy soil and the herb community, with a dominant species Echium vulgare, or Arrhenatherum elatius. Therefore plots closest to the river, where the positive effect of vegetation is expected is settled by Fallopia japonica which can contrariwise support the erosion of sediments. As we calculated, the rate of spread might be very dangerous and lowering the ecological quality in this protected area.

The flood of May 2014 had an intensity of about 4.5 years water $\left(91.7 \mathrm{~m}^{3} \mathrm{~s}^{-1}\right)$, and during this kind of flood with those growing and soil conditions, the thickness of the humus horizon on the evaluated plots is mostly affected by the distance from the water flow. When evaluating vegetation parameters, it was found that, surprisingly, a higher cover reduces the amount of settled material and increases erosion in the humus horizon.

Similarly surprising, dependence concerns also affect the maximum height of plants. Erosion increases and sedimentation reduces with increasing maximum plant height. These surprising dependences are not the result of vegetation effect but are related to the dominant influence of distance from a watercourse on erosion-accumulative processes. Distance from water has a strong impact on the decrease of the shear stress which during the flood effects on the soil surface. At the same time the negative correlation between the distance from a watercourse and vegetation coverage/maximum plant height was observed. The impact of this factor therefore masks the effect of vegetation characteristics.

From the recorded changes in the humus layer thicknesses during flood events it can be concluded, that the erosion-accumulative processes were dominantly controlled by changes in shear stresses, that were affecting the soil surface during the flood. Influence of shear stress has also enhanced by the spatial variation of grain composition of soils.

As already mentioned, the results indicate that vegetation promote erosion and negatively affect sediment accumulation. Such correlation relationships apparently cannot be a causal relationship but it is only a seeming correlation. Effect of vegetation in the studied riparian zone is masked by the influence of spatial change of vegetation characteristics. In the matter of fact, very strong negative correlation was recorded for the relationship between the distance from the water body and vegetation coverage, respectively maximum plant height.

Phytocoenological characterization can help when performing future research in this area and monitoring of the invasive species spreading is suggested for evaluation during future flood events.

Acknowledgements. This research was supported by the Scientific grant Agency of the Ministry of Education, Science and Sport of the Slovak Republic (VEGA 1/0096/16). 


\section{REFERENCES}

[1] Arnold, E., Toran, A. (2018): Effects of bank vegetation and incision on erosion rates in an urban stream. - Water 10(4): 482. DOI: 10.3390/w10040482.

[2] Boudell, J. A., Dixon, M. D., Rood, S. B., Stromberg, J. C. (2015): Restoring functional riparian ecosystems: concepts and applications. - Ecohydrology 8: 747-752. DOI: 10.1002/eco.1664.

[3] Braun-Blanquet, J. (1964): Pflanzensoziologie. Grundzüge der Vegetationskunde. Ed. 3. - Springer, Wien-New York.

[4] Bywater-Reyes, S., Wilcox, A. C., Stella, J. C., Lightbody, A. F. (2015): Flow and scour constraints on uprooting of pioneer woody seedlings. - Water Resources Research 51(11): 9190-9206. DOI: 10.1002/2014WR016641.

[5] Camporeale, C., Perucca, E., Ridolfi, L., Gurnell, A. M. (2013): Modelling the interactions between river morphodynamics and riparian vegetation. - Reviews of Geophysics 51(3): 379-414. DOI: 10.1002/rog.20014.

[6] Capon, S. J., Chambers, L. E., Mac Nally, R., Naiman, R. J., Davies, P; Marshall, N. et al. (2013): Riparian ecosystems in the 21st Century: hotspots for climate change adaptation? - Ecosystems 16(3): 1-23. DOI: 10.1007/s10021-013-9656-1.

[7] Catford, J. A., Morris, W. K., Vesk, P. A., Gippel, C. J., Downes, B. J. (2014): Species and environmental characteristics point to flow regulation and drought as drivers of riparian plant invasion. - Diversity and Distributions 20: 1084-96. DOI: 10.1111/ddi.12225.

[8] Clarke, L. E. (2014): The use of live vegetation in geomorphological experiments: how to create optimal growing conditions. - Earth Surface Processes and Landforms 39(5): 705710. DOI: $10.1002 /$ esp.3534.

[9] Claude, N., Leroux, C., Duciercq, M., Tassi, P., Abderrezzak, K. K. (2018): Limiting the development of riparian vegetation in the Isére River: A physical modelling study. - E3S Web of Conferences 40: 02015. DOI: 10.1051/e3sconf/20184002015.

[10] Corenblit, D., Steiger, J., Gurnell, A. M., Tabacchi, E., Roques, L. (2009): Control of sediment dynamics by a vegetation as a key function driving biogeomorphic succession within fluvial corridors. Earth Surf. Process. - Landforms 34: 1790-1810. DOI: 10.1002/esp.1876.

[11] Corenblit, D., Steiger, J., Tabacchi, E., Gonzáles, E., Planty-Tabacchi, A. M. (2014a): Ecosystem engineers modulate exotic invasions in riparian plant communities. - River Research and Applications 30(1): 45-59. DOI: 10.1002/rra.2618.

[12] Corenblit, D., Steiger, J., González, E., Gurnell, A. M., Charrier, G., Darrozes, J., Dousseau, J., Julien, F., Lambs, L., Larrue, S., Roussel, E., Vautier, F., Voldoire, O. (2014b): The biogeomorphological life cycle of poplars during the fluvial biogeomorphological succession: a special focus on Populus nigra. - Earth Surface Processes and Landforms 39(4): 546-563. DOI: 10.1002/esp.3515.

[13] Daigneault, A. J., Eppink, F. V., Lee, W. G. (2017): A national riparian restoration programme in New Zealand: Is it value for money? - Journal of Environmental Management 187(1): 166-177. DOI: 10.1016/j.jenvman.2016.11.013.

[14] van Dijk, W. M., Teske, R., van de Lageweg, W. I., Kleinhans, M. G. (2013): Effects of vegetation distribution on experimental river channel dynamics. - Water Resources Research 49: 7558-7574. DOI: 10.1002/2013WR013574.

[15] Dufour, S., Massimo, R., Piégay, H., Amael, M. (2015): How do river dynamics and human influnces affect the landscape pattern of fluvial corridors? Lessons from the Magra River, Central -Northern Italy. - Landscape and Urban Planning 134: 107-118. DOI: 10.1016/j.landurban.2014.10.007.

[16] Dyderski, M. K., Gdula, A. K., Jagodziński, A. M. (2015): "The rich get richer" concept in riparian woody species. A case study of the Warta River Valley (Poznań, Poland). Urban Forestry \& Urban Greening 14(1): 107-114. DOI: 10.1016/j.ufug.2014.12.003. 
[17] Eichel, J., Krautblatter, M., Schmidtlein, S., Dikau, R. (2013): Biogeomorphic interactions in the Turtmann Glacier forfield, Switzerland. - Geomorphology 201: 98110. DOI: 10.1016/j.geomorph.2013.06.012.

[18] Egger, G., Politi, E., Angermann, K., Schneider, M., Kopecki, I., Habersack, H., Blamauer, B., Sattler, S., Mayr, P. (2013a): EcoRiver Linking riparian vegetation and hydrodynamic processes: an integrated dynamic simulation model. - Technical Report 2112650: 2013.

[19] Egger, G., Politi, E., Garófano-Gómez, V., Blamauer, B., Fereira, M. T., Rivales, R., Benjankar, R. et al. (2013b): Embodying Interactions of Riparian Vegetation and Fluvial Processes into a Dynamic Floodplain Model: Concepts and Applications. - In: Maddock, I., Harby, A., Kemp, P., Wood, P. (eds.) Ecohydraulics: An Integrated Approach. John Wiley \& Sons Ltd, New York.

[20] Funk, A., Martinéz-Lopéz, J., Borgwardt, F., Trauner, D., Bagstad, K. J., Balbi, S., Magrach, A., Villa, F., Hein, T. (2019): Identification of conservation and restoration priority areas in the Danube River based on the multi-functionality of river-floodplain systems. - Science of the Total Environment 654: 763: 777. DOI: 10.1016/j.scitotenv.2018.10.322.

[21] Garcia-Arias, A., Francés, F. (2015): The RVDM model: modelling impacts, evolution and competition processes to determine riparian vegetation dynamics. - Ecohydrology 9(3): 438-459. DOI: 10.1002/eco.1648.

[22] Garssen, A. G., Verhoeven, J. T. A., Soons, M. B. (2014): Effects of climate-induced increases in summer drought on riparian plant species: a meta-analysis. - Freshwater Biology 59(5): 1052-1063. DOI: 10.1111/fwb.12328.

[23] Gilyear, D. J., Greenwood, M. T., Thoms, M. C. (2017): Large wood produced by riparian forests can also protect reinforce and stabilise landfroms. - Front Plant Science 8: 1612. DOI: $10.3389 /$ fpls.2017.01612.

[24] Gonzáles, E., Cabezas, A., Corenblit, D., Steiger, J. (2014): Autochthonous versus allochthonous organic matter in recent soil $\mathrm{C}$ accumulation along a floodplain biogeomorphic gradient: an exploratory study. - Journal of Environmental Geography 7(1-2): 29-38. DOI: 10.2478/jengeo-2014-0004.

[25] González, E., Sher, A. A., Tabacchi, E., Masip, A., Poulin, M. (2015): Restoration of riparian vegetation: A global review of implementation and evaluation approaches in the international, peer-reviewed literature. - Journal of Environmental Management 158: 8594. DOI: $10.1016 /$ j.jenvman.2015.04.033.

[26] Gurnell, A. M. (2014): Plants as river system engineers. - Earth Surface Processes and Landforms 39(1): 4-25. DOI: 10.1002/esp.3397.

[27] Gurnell, A. M., Corenblit, D., García de Jalón, D., González del Tánago, M., Grabowski, R. C., O’Hare, M. T., Szewczyk, M. (2016a): A conceptual model of vegetationhydrogeomorphology interactions within river corridors. - River Research and Applications 32(2): 142-163. DOI: 10.1002/rra.2928.

[28] Gurnell, A. M., Rinaldi, M., Buijse, A. D., Brierley, G., Piégay, H. (2016b): Hydromorphological frameworks: emerging trajectories. - Aquatic Sciences: Research Across Boundaries 78(1): 135-138. DOI: http://dx.doi.org/10.1007/s00027-015-0436-1.

[29] Habersack, H., Hein, T., Stanica, A., Liska, I., Mair, R., Jager, E., Hauer, C., Bradley, C. (2016): Challenges of river basin management: Current status of, and prospects for, the River Danube from a river engineering perspective. - Science of the Total Environment 543(A): 828-845. doi: 10.1016/j.scitotenv.2015.10.123

[30] Havel, J. E., Kovalenko, K. E., Thomaz, S. M., Amalfitano, S., Kats, L. B. (2015): Aquatic invasive species: challenges for the future. - Hydrobiologia 750(1): 147-170. DOI: $10.1007 / \mathrm{s} 10750-014-2166-0$.

[31] Hennekens, S. (1998-2012): Turboveg for Windows. - Version 2.

[32] Hession, W. C., Curran, J. C. (2013): The Impacts of Vegetation on Roughness in Fluvial Systems. - In: Shroder, J. F., Butler, D. R., Hupp, C. R. (eds.) Treatise on 
Geomorphology. Vol 12. Ecogeomorphology. Academic Press, San Diego. DOI: 10.1016/B978-0-12-374739-6.00323-7.

[33] Kazakova, A. I., Semikolennykh, A. A., Gornov, A. V., Gornova, M. V., Lukina, N. V. (2018): Influence of vegetation on the lability characteristics of sandur areas of the Bryansky Les Nature Reserve. - Moscow University Soil Science Bulletin 73(3): 100106. https://doi.org/10.3103/S0147687418030055.

[34] Kath, J., Reardon-Smith, K., Le Brocque, A. F., Dyer, F. J., Dafny, E., Fritz, L., Batterham, M. (2014): Groundwater decline and tree change in floodplain landscapes: Identifying non-linear threshold responses in canopy condition. - Global Ecology and Conservation 2: 148-160. https://doi.org/10.1016/j.gecco.2014.09.002.

[35] Kim, D., Kupfer, J. A. (2016): Tri-variate relationships among vegetation, soil and topography along gradients of fluvial biogeomorphic succession. - PLoS One 11(9): e0163223. DOI: 10.1371/journal.pone.0163223.

[36] Kondolf, M. G, Piégay, H. (eds.) 2016: Tools in Fluvial Geomorphology. - WileyBlackwell, New York.

[37] Kui, L., Stella, J. C. (2016): Fluvial sediment burial increases mortality of young riparian trees but induces compensatory growth response in survivors. - Forest Ecology and Management 366: 32-40. DOI: 10.1016/j.foreco.2016.02.001

[38] Kui, L., Stella, J. C., Lightbody, A., Wilcox, A. C. (2014): Ecogeomorphic feedbacks and food loss of riparian tree seedlings in meandering channel experiments. - Water Resources Research 50: 9366-9384. DOI: 10.1002/2014WR015719.

[39] Lamb, M. P., Brun, F., Fuller, B. M. (2017): Hydrodynamics of steep streams with planar coarse-grained beds: Turbulence, flow resistance, and implications for sediment transport. - Water Resources Research 53(3): 2240-2263. DOI: 10.1002/2016WR019579.

[40] Li, S., Xia, X., Tan, X., Zhang, Q. (2013): Effects of catchment and riparian landscape setting on water chemistry and seasonal evolution of water quality in the Upper Han River Basin, China. $\quad-\quad$ PLoS ONE 8(1): e53163. https://doi.org/10.1371/journal.pone.0053163

[41] Liu, C., Neph, H. (2016): Sediment deposition within and around a finite patch of model vegetation over a range of channel velocity. - Water Resources Research 52(1): 600-612. DOI: 10.1002/2015WR018249.

[42] Macura, V., Škrinár, A., Kalúz, K., Jalčovíková, M., Škrovinová, M. (2012): Influence of the morphological and hydraulic characteristics of mountain streams on fish habitat suitability curves. - River Research and Applications 28(8): 1161-1178.

[43] Merritt, D. M. (2013): Reciprocal Relations between Riparian Vegetation, Fluvial Landforms, and Channel Processes. - In: Shroder, J. F., Wohl, E. (eds.) Fluvial Geomorphology. Vol. 9. Treatise on Geomorphology. Academic Press, San Diego. DOI: 10.1016/B978-0-12-374739-6.00323-7.

[44] Mobaied, S., Geoffroy, J. J., Machon, N. (2016): The importance of spatiotemporal heterogeneity for biodiversity in forest heathland mosaics and implications for heathland conservation. - Journal of Environmental Protection 7: 1317-1332. DOI: 10.4236/jep.2016.710115.

[45] O'Brian, R., Shephard, S., Coghlan, B.(2018): A river vegetation quality metric in ecohydromorphology philosophy. - River Research and Applications 34(3): 207-217. DOI: $10.1002 /$ rra.3244.

[46] van Oorschot, M., Kleinhans, M. G., Geerling, G. W., Egger, G., Leuven, R. S. E. W., Middelkoop, H. (2017): Modeling invasive alien plant species in river systems: Interaction with native ecosystem engineers and effects on hydro-morphodynamic processes. - Water Resources Research 53(8): 6945-6969.

[47] Opperman, J. J., Moyle, P., Larsen, E. W., Florsheim, J. L., Manfree, A. D. (2017): Floodplains: Processes and Management for Ecosystem Services. - University of California Press, California. 
[48] Passarelli, C., Olivier, F., Paterson, D. M., Meziane, T., Hubas, C. (2014): Organisms as cooperative ecosystem engineers in intertidal flats. - Journal of Sea Research 92: 92-101. DOI: 10.1016/j.seares.2013.07.010.

[49] Rinaldi, M., Surian, N., Comiti, F., Bussettini, M. (2013): A method for the assessment and analysis of the hydromorphological condition of Italian streams: the morphological quality index (MQI). - Geomorphology 180-181(0): 96-108. DOI: 10.1016/j.geomorph.2012.09.009.

[50] Rinaldi, M., Surian, N., Comiti, F., Bussettini, M. (2015): A methodological framework for hydromorphological assessment, analysis and monitoring (IDRAIM) aimed at promoting integrated river management. - Geomorphology 251(15): 122-136. DOI: 10.1016/j.geomorph.2015.05.010.

[51] Rivaes, R., Pinheiro, A. N., Egger, G., Ferreira, T. (2014): The role of river morphodynamic disturbance and groundwater hydrology as driving factors of riparian landscape patterns in Mediterranean Rivers. - Freshwater Biology 59(5): 1052-1063. DOI: $10.1111 / \mathrm{fwb} .12328$.

[52] Rössler, N., Egger, G., Drescher, A. (2018): Fluvial processes and changes in the floodplain vegetation of the Vjosa River (Albania). - Acta ZooBot Austria 155: 73-84.

[53] Sankey, J. B., Ralston, B. E., Grams, P. E., Schmidt, J. C., Cagney, L. E. (2015): Riparian vegetation, Colorado River, and climate: five decades of spatiotemporal dynamics in the Grand Canyon with river regulation. - Journal of Geophysical Research G: Biogeosciences 120(8): 1532-1547. DOI: 10.1002/2015JG002991.

[54] Solari, L., Van Oorschot, M., Hendriks, D., Rinaldi, M., Vargas-Luna, A. (2015): Advances on modelling riparian vegetation-hydromorphology interactions. - River Research and Applications 32(2): 164-178. DOI: 10.1002/rra.2910.

[55] Sponseller, R. A., Heffernan, J. B., Fisher, S. G. (2013): On the multiple ecological roles of water in river networks. - Ecosphere 4(2): 17. http://dx.doi.org/10.1890/ES12-00225.1

[56] Stallings, K. D., Seth-Carley, D., Richardson, R. J. (2015): Management of aquatic vegetation in the southeastern United States. - Journal of Integrated Pest Management 6(1): 3. http://dx.doi.org/10.1093/jipm/pmv002.

[57] Surian, N., Barban, M., Ziliani, L., Monegato, G., Bertoldi, W., Comiti, F. (2015): Vegetation turnover in a braided river: frequency and effectiveness of floods of different magnitude. - Earth Surface Processes and Landforms 40(4): 542-558. https://doi.org/10.1002/esp.3660.

[58] Tagwireyi, P., Sullivan, M. P. (2015): Riverine landscape patch heterogeneity drives riparian ant assemblages in the Scioto River Basin, USA. - PLoS ONE 10(4): e0124807. DOI: 10.1371/journal.pone.012480.

[59] Thomas, L. K., Mosner, E., Leyer, I. (2015): River dynamics and invasion: distribution patterns of native and invasive woody vegetation at the Río Negro, Argentina. - Riparian Ecol. Conserv. 2: 45-57. DOI: 10.1515/remc-2015-0001.

[60] Varigin, A. Y. (2018): Biotic links in the fouling community of Odessa Bay (Black Sea). - Biosystems Diversity 26(1): 24-29. DOI: 10.15421/011804.

[61] Warner, A. T., Bach, L. B., Hickey, J. T. (2014): Restoring environmental flows through adaptive reservoir management: planning, science and implementation through the Sustainable Rivers Project. - Hydrological Sciences Journal 59(3-4): 770-785.

[62] Wohl, E. E., Bledsoe, B. P., Jacobson, B. R., Poff, N. L., Ratburn, S. L., Walters, D. M., Wilcox, A, C. (2015): The natural sediment regime in rivers: broadening the foundation for ecosystem management. - BioScience 65(4): 358-371. DOI: 10.1093/biosci/biv002. 